

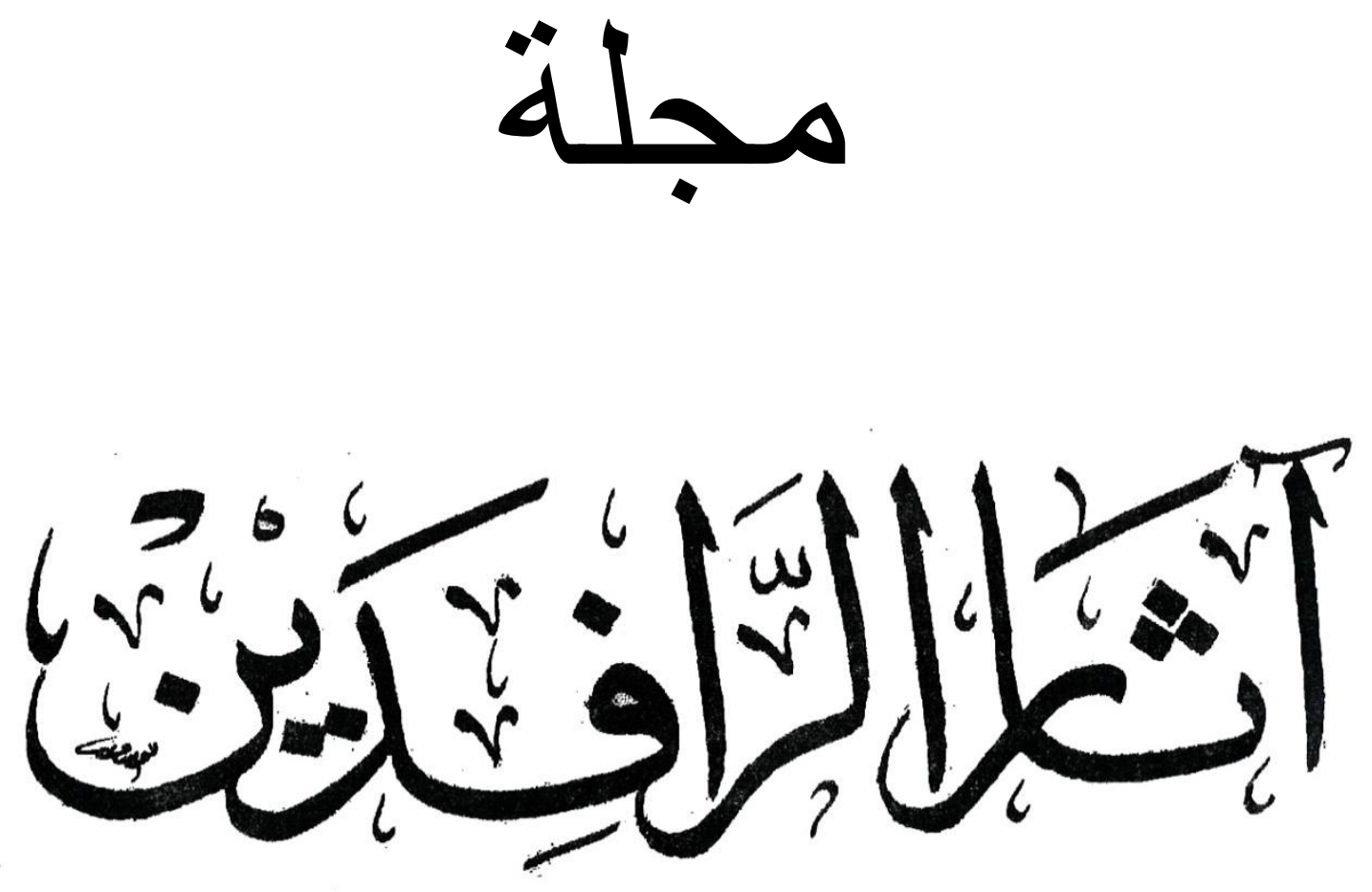

هجلة علمية همكمة تبحث في آثار العراق و الشرق الأدنى القديم تصدر عن كلية الآثار في جاهعة الموصل

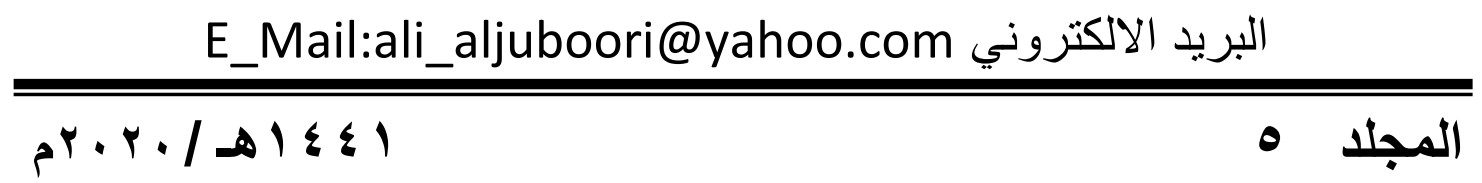



رقم الإِيداع في دار الكتب و الوثائق ببغداد

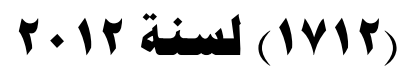





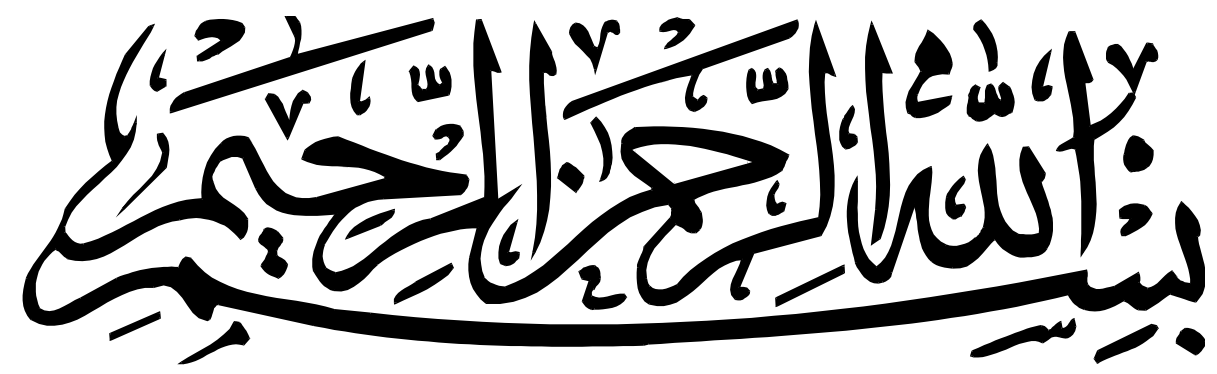





$$
\text { أ.د. علي ياسية التمرير الجبوري }
$$

$$
\begin{aligned}
& \text { أ.م.د. فيان هوفق رشيد النعيمي } \\
& \text { أ.د. صفوان ساهي سعيد الرفاعي } \\
& \text { سكرتير التصرير } \\
& \text { نائب رئيس التمرير }
\end{aligned}
$$

الأوضاs

أ.د. شعلان كاهل اسماعيل

أ.د. عاهر عبدالاله نجم الجُميلي

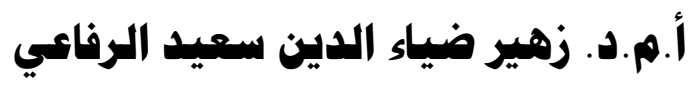

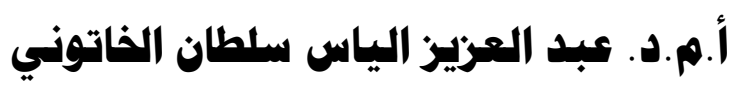

$$
\begin{aligned}
& \text { الخبير الاغوي } \\
& \text { أ.م.د. همن يميى هممد العبادي } \\
& \text { كلية الآداب - جاهعة الموصل } \\
& \text { الهيأة الاستشارية }
\end{aligned}
$$

جامعة الموصل

جاهمة بغداد

جاهعة الموصل

جامعة الموصل

جاهمة الموصل

جاهعة القادسية

جاهعة الكوفة 



\section{قواعد النشر في المبلة}

• يشترط أن يكون البحث ضهن الاختصاصات التي تُعنى بها المجلة • يشترط على الباحث الالتزام بالموضوعية و المنهج العلمي في البحث و التحليل ،و أن يلتزه بشروط البحث العلمي هن حيث التبويب و استعمال الهواهش و الإشارة إلى المصادر و المراجع وفق طريقة هنهجية و احدة ،و في

$$
\text { آخر البحث }
$$

• يشترط على الباحث هراعاة الجوانب الشكلية و الاهتهام بسلاهة لغة البحث هن الأخطاء اللغوية و المطبعية

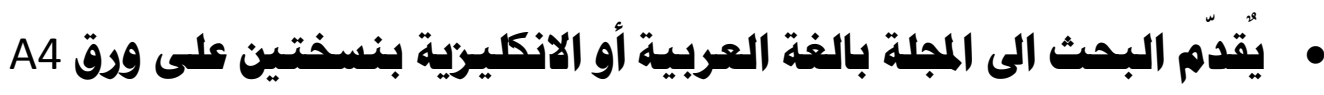
• يرافق البحث في أوله هلخص" باللغة الانكليزية على أن لا يريد عدد كلماته

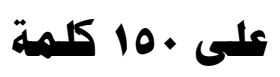

• يشترط أن لا يكون البحث قد نشر او قبل للنشر في أيّة دورية علمية داخل

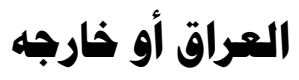

• يشترط على الباحث أن لا تتجاوز عدد صفحات بثه عن ro صفحة • يشترط في البحث أن تكون المشاهد و الأشكال الفنية المرافقة له عالية الجودة • أصول البحث المقدهة إلى البلة لا ترد أو تُسترجع سواء نشرت أم لم تنشر • تعتمد المجلة هبدأ التمويل الذاتي وتهدد أجور النشر في ضوء الأسعار السائدة 

ثبت المحتويات

\begin{tabular}{|c|c|c|}
\hline العنوان & اسم الباحث & الصفحة \\
\hline توطئة & أ.د. علي ياسين الجبوري & 1 \\
\hline نعي - الراحل الأستاذ الدكتور عبد القادر عبد الجبار مصطفى الثيخليّ & أ.د. جابر خليل إبراهيم & r \\
\hline ملحمة كلكامش : الاصالة والتأثير & أ.د. علي ياسين الجبوري & $r r-V$ \\
\hline نصوصُ اقتصاديةٌ غيرُ منشورةٍ مِنْ عَهْذِ المللكِ شو - سين & أ. خالد سالم اسماعيل & TI-r \\
\hline معالجة رُقُم طينية من متحف السليمانية & أ. أ. خالد سالم اسماعيل & $R V-74$ \\
\hline تسويق المنتجات الزراعية بين مدن العراق القيم & أ.د. حسين ظاهر حمود & $90-\vee 9$ \\
\hline 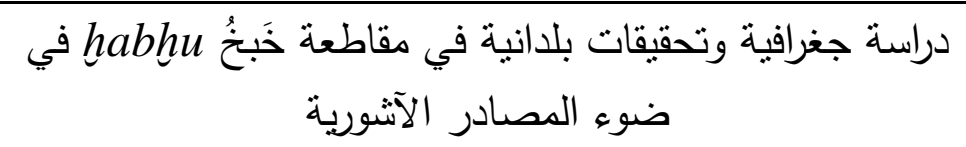 & أ. د. عامر عبد الله الجميلي & $I Y V-9 V$ \\
\hline مظاهر الحرية والاستبداد في نظم الإدارة المركزية في المملكة & أ.د. صفوان سامي سعيد & $109-119$ \\
\hline شخصية الملوك الآشوريين وصفاتهم القيادية & عفراء يحيى قاسم أ.د. صفوان سامي سعيد & $19 \cdot-171$ \\
\hline تاريخ التتقيبات الأثريّة في مدينة نينوى & د. د. عبد الستار أحمد حسين & $(1) \leq-191$ \\
\hline 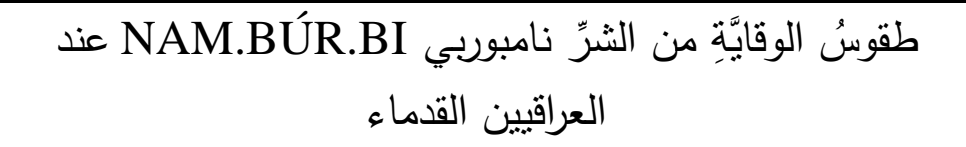 & د. نبيل خالد شيت سليمان & $r Y q-r 10$ \\
\hline الزواج بين النص المسماري والقرآني-دراسة مقارنة & أ. أ. نسرين أحمد عبد يحيى الجبوري & YTV-rTI \\
\hline عقود قرض غير منشورة من مدينة لاكَابا من العصر البابلي & م. آرام جلال حسن الهموندي & $r \wedge \Lambda-r T q$ \\
\hline الثـــكل والإعجام في الخطٌّ العربيّ & م·• وسن عبد المطلب حسن & $r \cdot V-r \wedge q$ \\
\hline تل الحويش (مدينة أوباسي؟) في الكتابات المسمارية والتحريات & م. غسان صالح الحميضة & $r r \leqslant-r \cdot q$ \\
\hline المواقعُ الجغرافيةُ لانتشارِ فخارِ العُبيد الثمالي & م.م. دريد سليم بولس & ratromo \\
\hline
\end{tabular}





\section{بسم الله الرحمن الرحيم \\ توطئة}

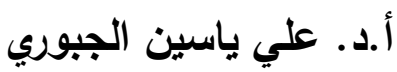

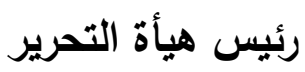

يصدر العدد الخامس من مجلة آثار الرافين الثابع لكلية الآثار - جامعة الموصل

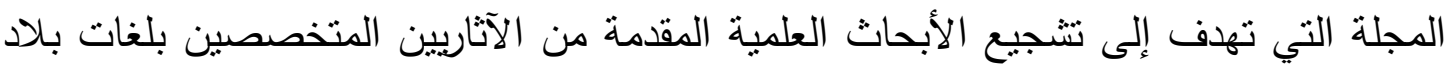

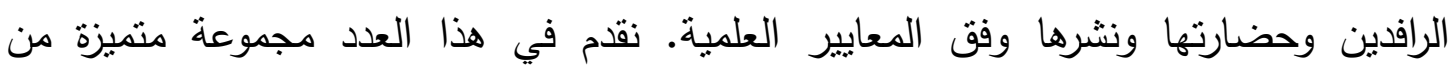

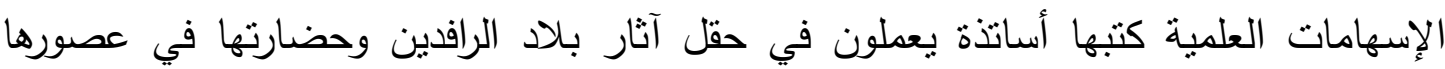

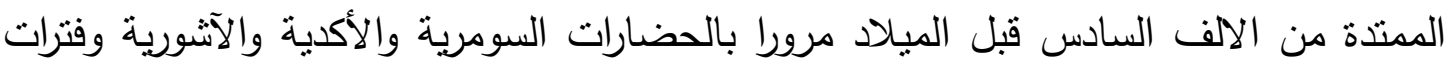

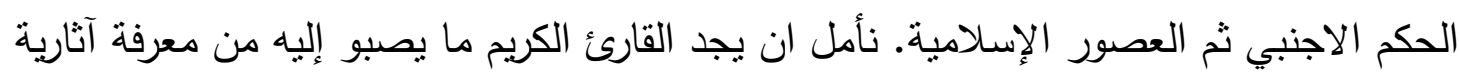

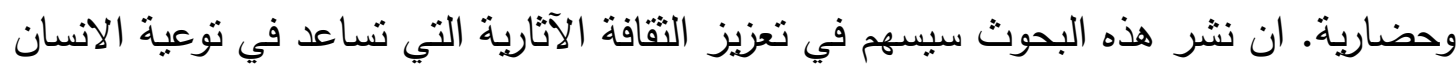

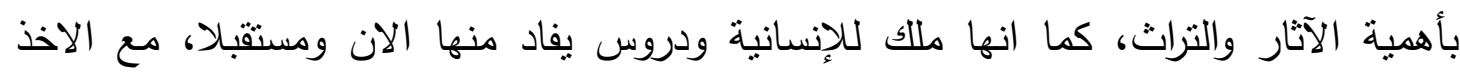

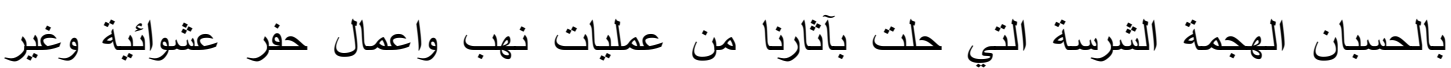

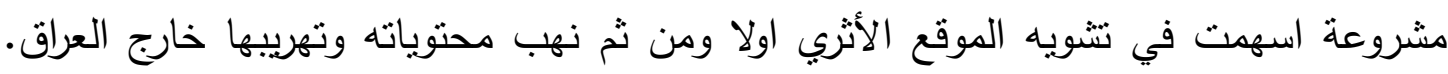

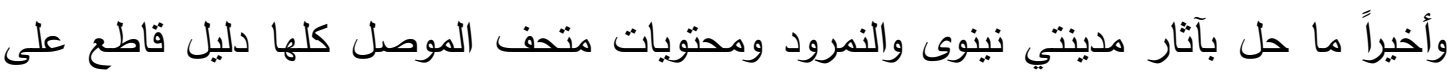

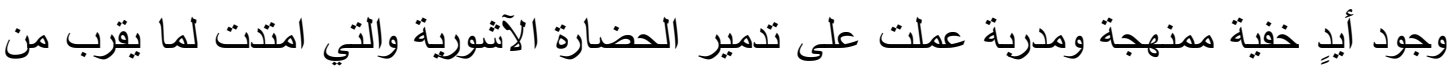
( ب.... T الف سنة قبل الميلاد.

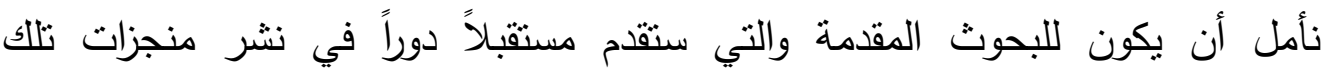

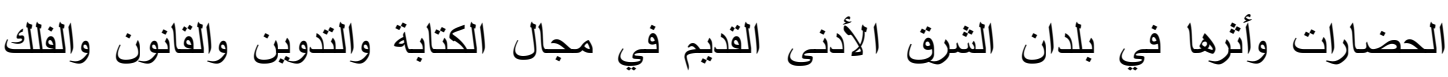
والتجيم والهندسة والرياضيات والطب والآداب بكل مجالاتئها.

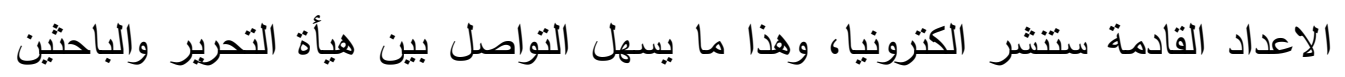
إن شاء الله. وستزود المجلة الباحثين بموقعها الجديد وكيفية التقديم اليها.

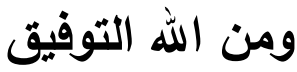





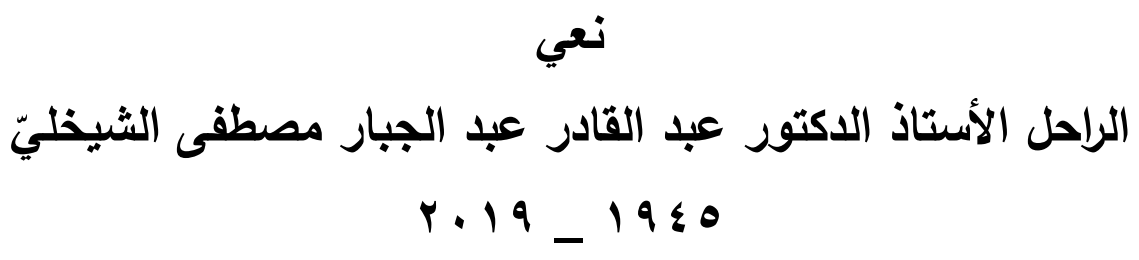

أ.د. - أد جابر خليل إبراهيم

كلية الآثار - جامعة الموصل

رئيس هيأة الآثار والتراث الأسبث

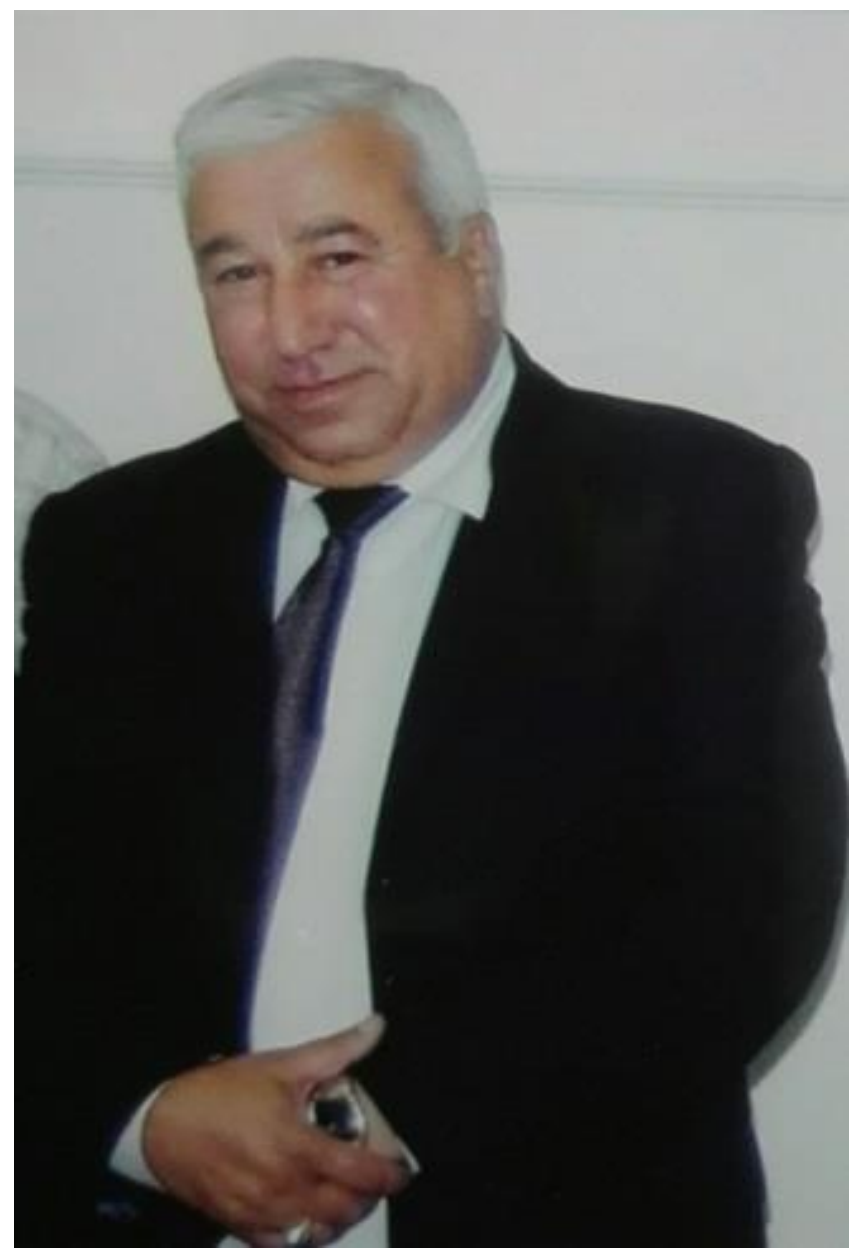

في يوم الجمعة الموافق •r أيلول 19 19 غادر الدكتور عبد القادر مطار بغداد الدولي منوجها الى مدينة اسطنبول بتركيا ، لإجراء فحوصات تتعلق بالقلب في إحدى مشافيها ، برافقه نجله أنس • بعد إجراء الفحوصات الطبية قرر الاطباء المختصين إجراء عملية جراحية كبرى في القلب .

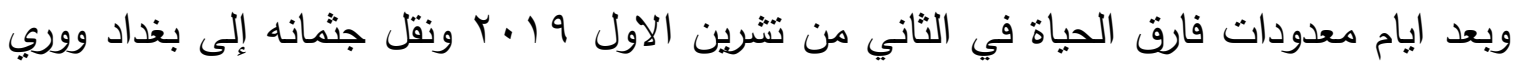

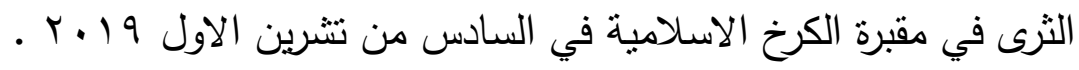


والفقد حالة مؤلمة ، والفراق هاجس مرعب ييقى كامناً في ذهن الإنسان وإن كان تفسيره هو انتقال من حياة زائلة إلى أخرى دائمة مستقرة .

ولد الفقيد عام 19 1 في حي عريق من أحياء مدينة بغداد معروف باسم (باب الثيخ ) نسبة إلى الثيخ الزاهد عبد القادر بن موسى بن عبداله الجيلي (الكيلاني) الذي فيه مرقده ومسجده دئه · الجامع أكمل المرحوم عبدالقادر دراسته الابتدائية والإعدادية في مدارس بغداد ثم التحق بعدها بقسم الآثار في كلية الآداب بجامعة بغداد وحصل على شهادة البكالوريوس في الاثار القديمة ـ وأهلته شهادته

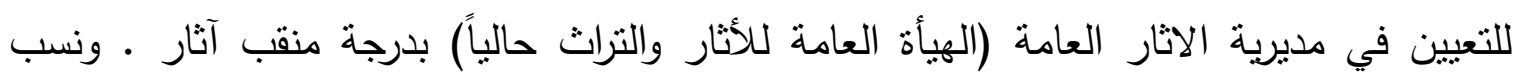
للعمل في دائرة التحريات وحماية المواقع الاثرية ـ والتحق يومئذٍ باللجان التي كانت تعد مؤلفين

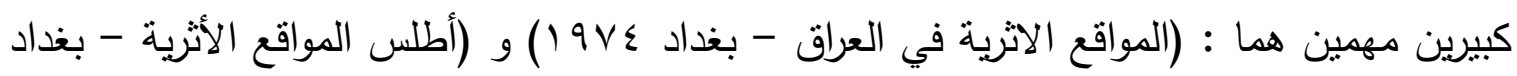

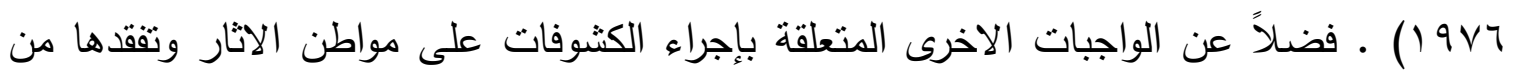
حين لآخر ، من أجل حمايتها من التجاوزات . في بداية شهر آذار من سنة 19 آشحت مديرية الاثار العامة يومها المرحوم عبد القادر

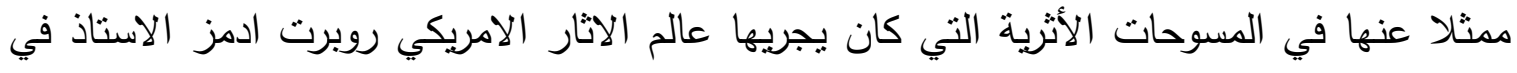

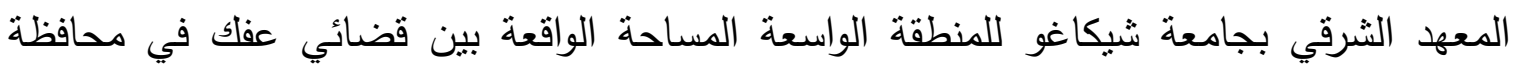

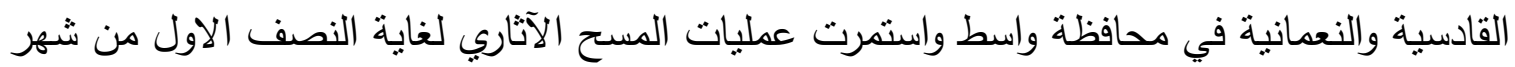
مارس من العام نفسه ـ والهدف من هذه المسوحات هو استكمال الدراسات الخاصة بمجاري الانهار والجداول الدارسة ، والتي كانت تروي المدن والقرى والحقول والبساتين في العصور القديمة ، والتي

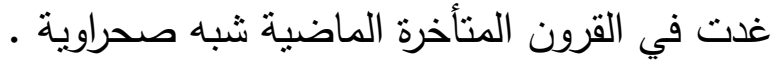
ومن الجدير بالذكر أن الاستاذ ادمز بدأ مشروعه هذا على مراحل ـ كانت الاولى في عام

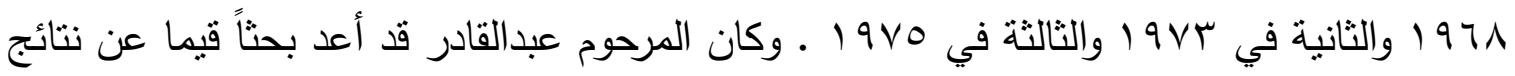

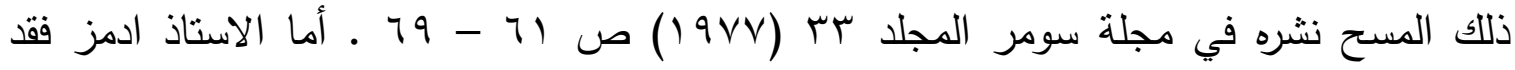
أصدر مؤلفه الثهير (Heartland Cities , Chicago 1981) كانت الأعمال الاثارية هذه علاوة على أعمال المسوحات في منطقة السهل الرسوبي ، قد أكسبت الفقيد مهارة في التحري والتتقيب التي

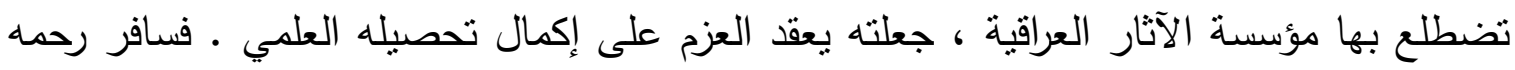

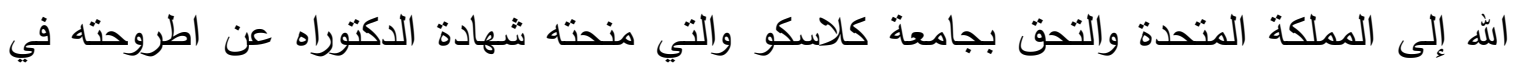


النصوص المسمارية المكتشفة في تليين مشهورين بحوض سهل حمرين هما (السيب وحداد) الواقعين

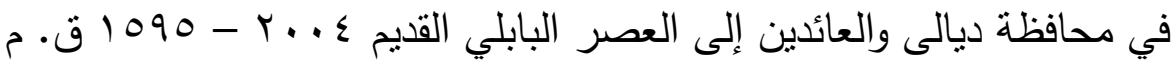

\section{The Old Babylonian Tablets From ME - TURAN (Tell AL SIB and Tell} HADAD) Univiersity of Glasgow June 1983

عاد الدكتور عبدالقادر إلى العراق والتحق بمؤسسة الآثار التي منحته اجازة دراسية لإكمال

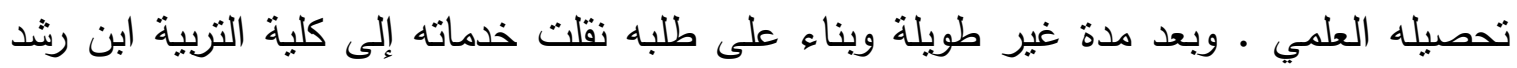
بجامعة بغداد لتدريس تاريخ العراق والوطن العربي في العصور القديمة إلا انه لم ينقطع عن دائرة الآثار والمتحف العراقي وفي الوقت نفسه كانت صلاته العلمية مع قسم الآثار بكلية الآداب في

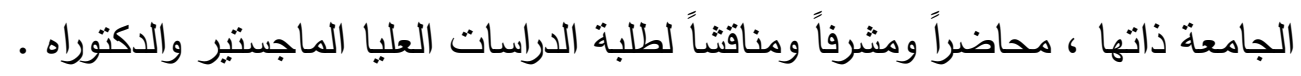
لم يقتصر نشاطه العلمي على كليته بل كان يلبي دعوات الجامعات العراقية لمناقتشة أطاريح

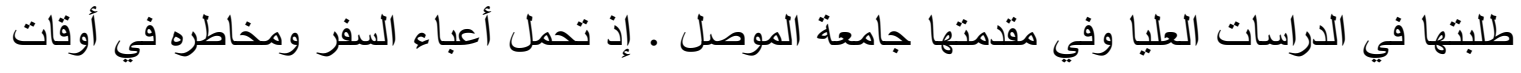

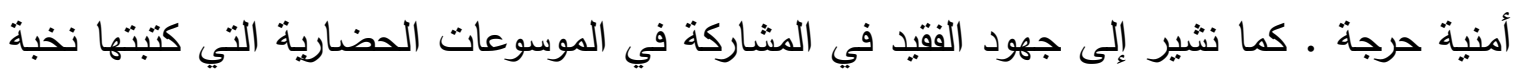

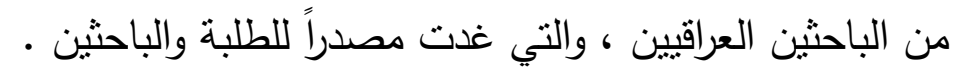

وفضلاً عن ذللك فقد تخرج على يدي الفقيد العديد من الآثاريين والمؤرخين في العراق فأصبح

بعض تلاميذه يقودون العملية التربوية في المدارس والجامعات العراقية .

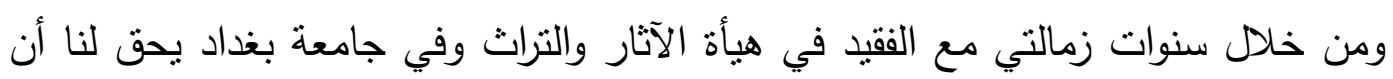

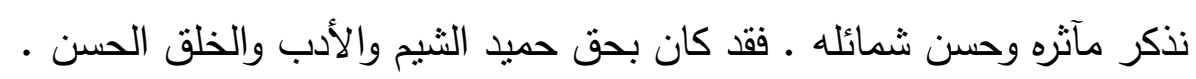

غادرنا المرحوم الدكتور عبدالقادر إلى عالم الآخرة وترك عند عند عائلئنه وزملائه وأصدقائه ومعارفه ومحبيه لوعة الحزن وألم الفراق ـ ندعو الله تعالى أن يتغده بواسع رحمته ، وأن يسكنه

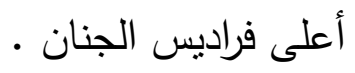

وإنا لله وإنا إليه راجعون 



\section{تاريخ التنقيات الأثريّة في مدينة نينوى}

كلية الآثار - مامعة من الموصل قاسم
د. دالِ الستار أحمد حسين

كلية الآثار - جامعة الموصل

الملخص

كان لورود اسماء بعض الددن القديمة ومنها مدينة نينوى في اخبار التوراة وروايات

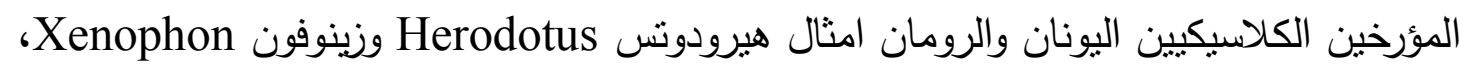

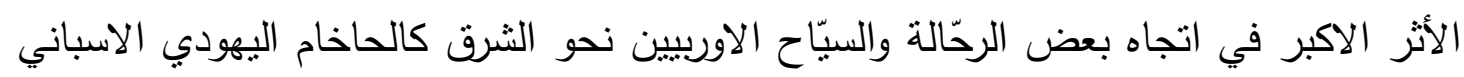

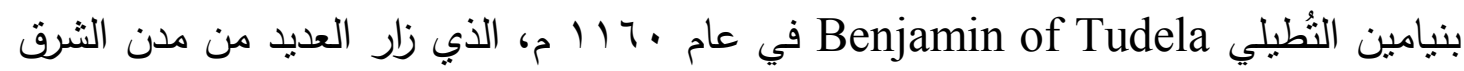
The Itinerary of Benjamin of ) ومنها مدينة نينوى وسجل مذكراته واخبار رحلته ( Tudela

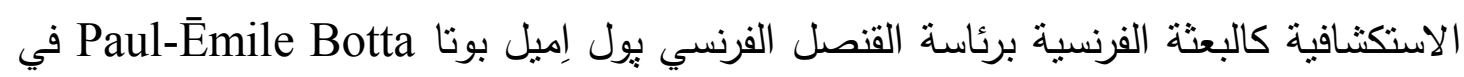

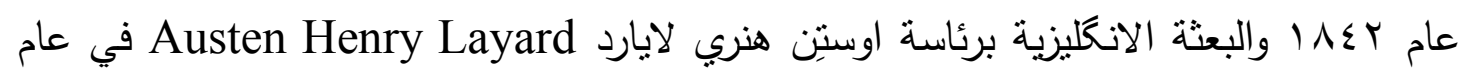

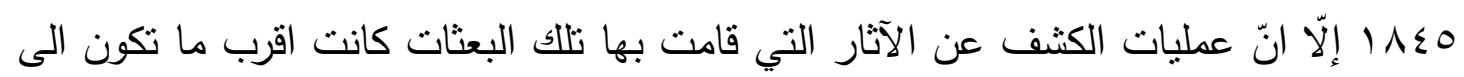

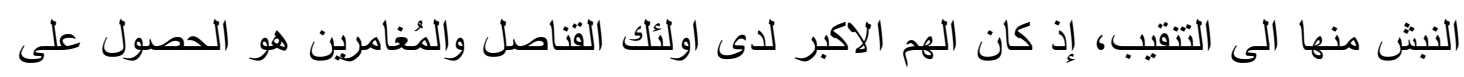

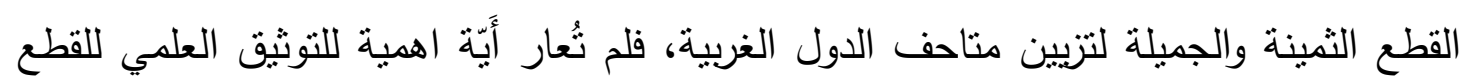
المكتشفة، فنتج عن تلاك الاخطاء ضياع معلومات انرية قَيَّمَة. أما طور التتقيات العلمية في العراق بصورة عامة فلم يبدأ حتى مطلع القرن العشرين

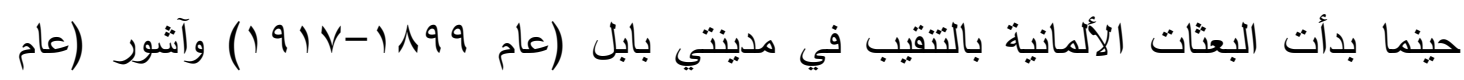

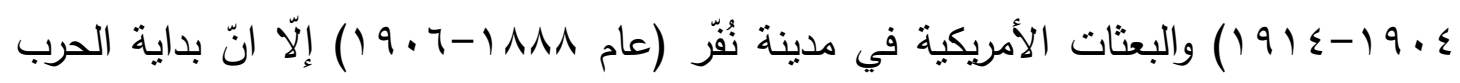

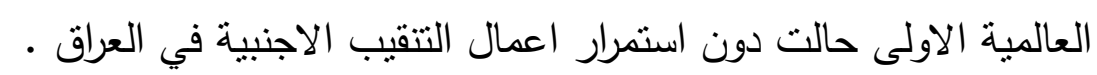

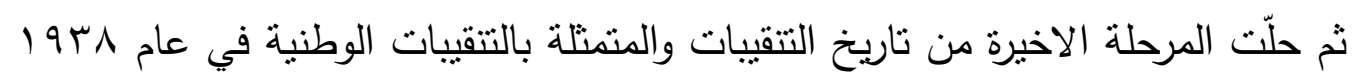

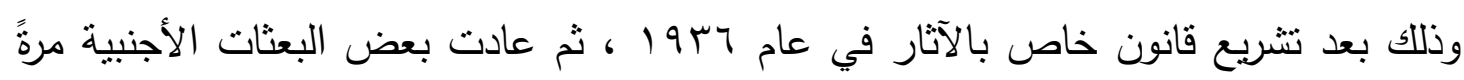

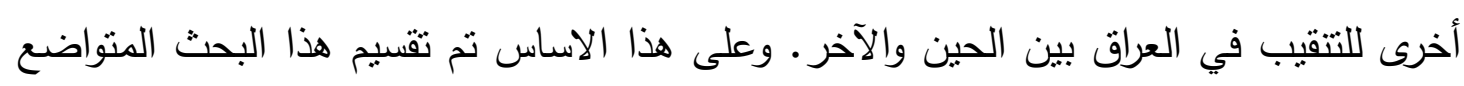

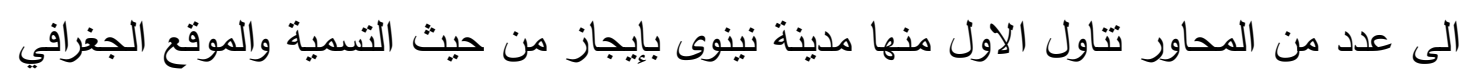

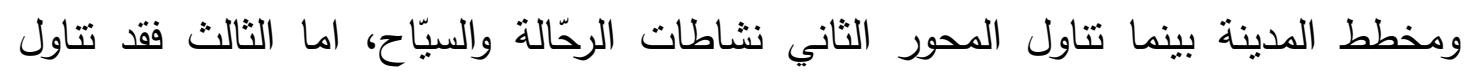
النشاطات الآثارية في القرن التاسع عشر، في حين تناول الدحور الرابع طور التنقيبات العلمية في القرن العشرين على يد البعثات الأجنبية والوطنية. 


\title{
History of Archaeological Excavations at Nineveh city
}

\section{Dr.'Abdul-Sattar Ahmed \\ Lecturer}

\author{
Munther Ali Qasim \\ Assistant Lecturer
}

\begin{abstract}
Mentioning the names of some ancient cities, including the city of Nineveh in the Bible and the historical narrations of Greek and Roman classical historians such as Herodotus and Xenophon, had the greatest influence in the movement of some European travelers and tourists to the East, such as the Jewish tourist of Spain, Benjamin of Tudela, in 1160.

The former, who visited Nineveh and recorded the activities of his journey that stimulated the activities of the European scientific institutions in the nineteenth century and sent its exploratory expeditions such as the French mission headed by the French consul Paul-Ëmile Botta in 1842 and the English mission headed by Austen Henry Layard in 1845. But, the archaeological discoveries carried out by those was closer to rummage rather than, namely, excavations. The biggest concern of these amateurs was to obtain precious and beautiful pieces to decorate the museums of the Western countries. However, no importance was attached to the scientific documentation of the discovered pieces. What resulted from those errors, the loss of valuable archaeological information.

The scientific excavations phase in Iraq, in general, did not begin until the beginning of the twentieth century when the German missions began drilling in the cities of Babylon and Ashur, but the beginning of World War I prevented the continuation of the foreign exploration works in Iraq.

Then, the final stage of the history of excavations was represented by the national excavations in 1938 after the enactment of a law concerned with archeology in 1936. On this basis, this modest research was divided into a number of chapters. The first of which discussed the city of Nineveh in terms of its geographical location, the importance of the city, its naming, history and layouts. The second chapter dealt with the activities of travelers and tourists. The third chapter dealt with the activities of the amateur prospectors. And, the fourth which is the final chapter studied the scientific exploration phase.
\end{abstract}




\section{المقدمة}

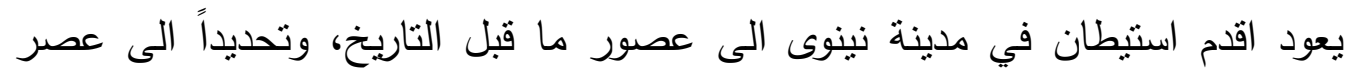

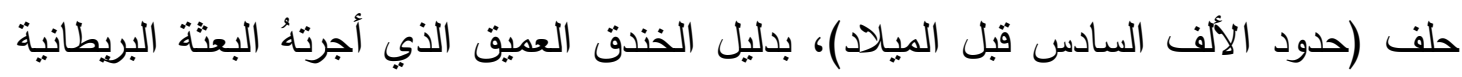

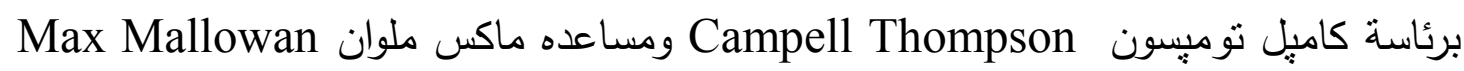

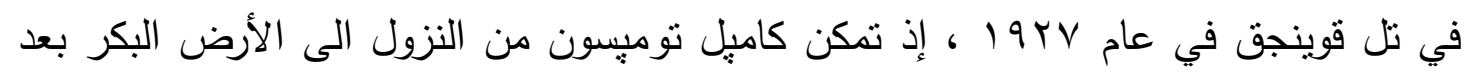

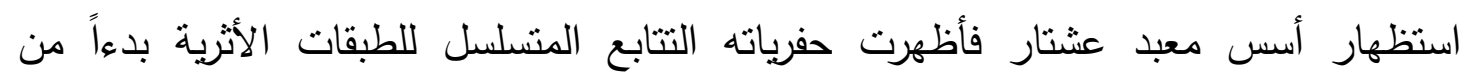

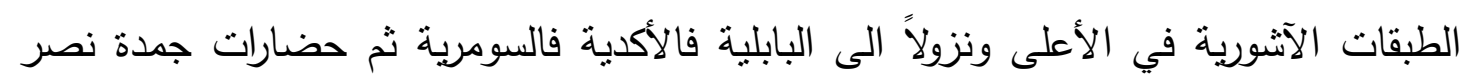

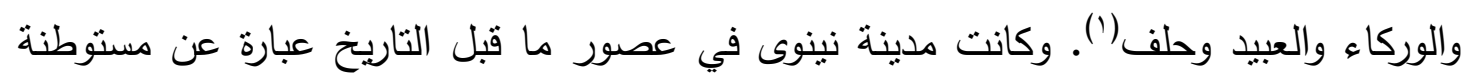

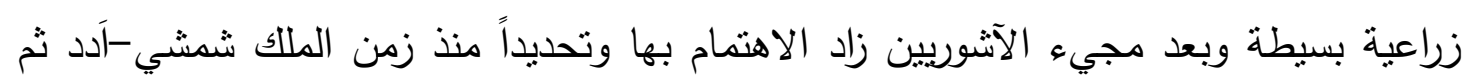

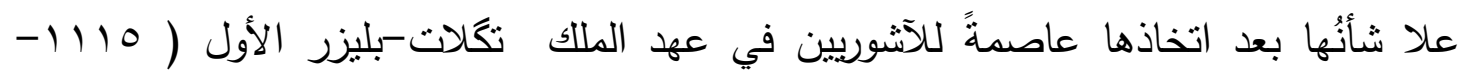
آل PV

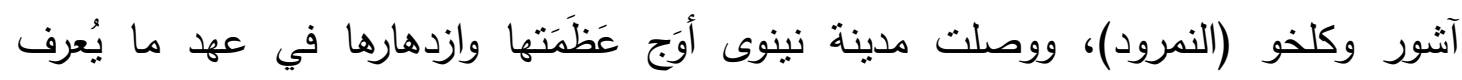

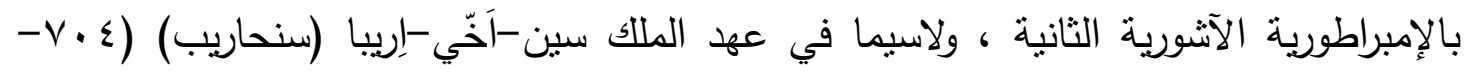

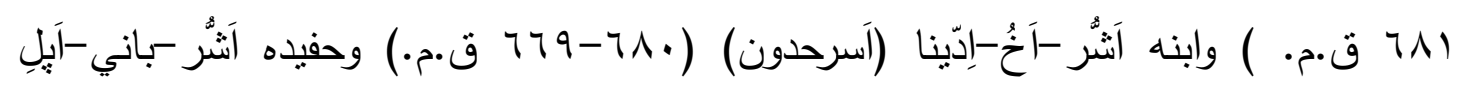

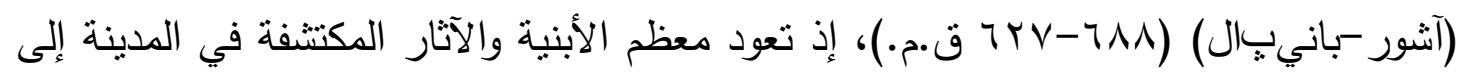

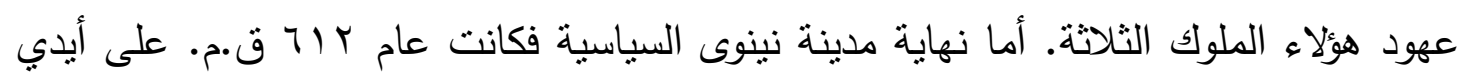

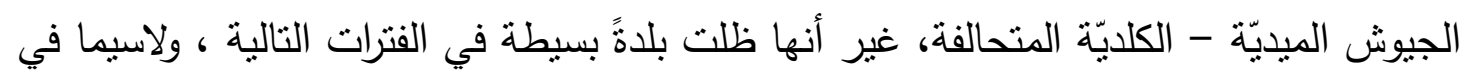

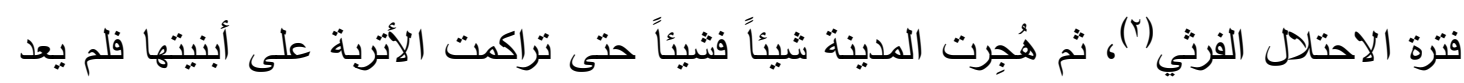

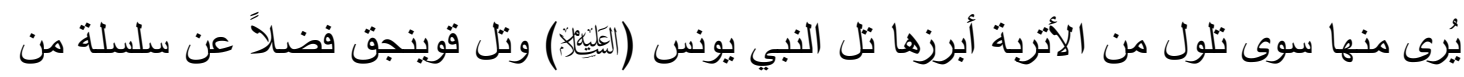

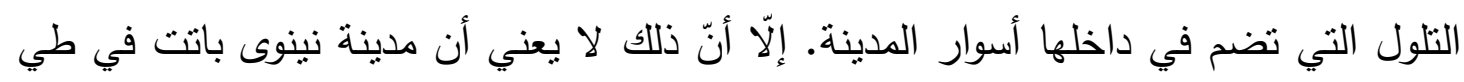

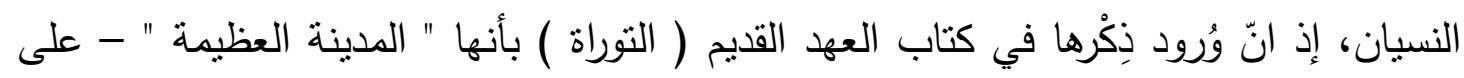

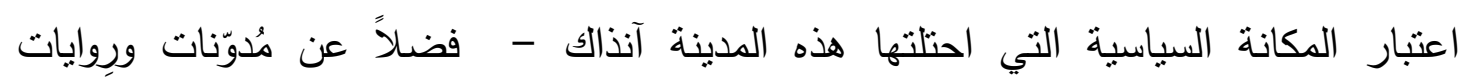

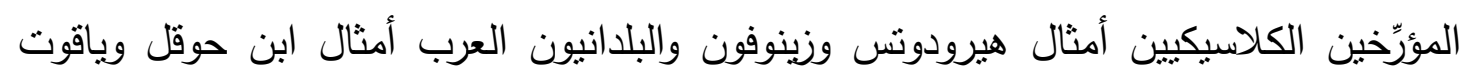

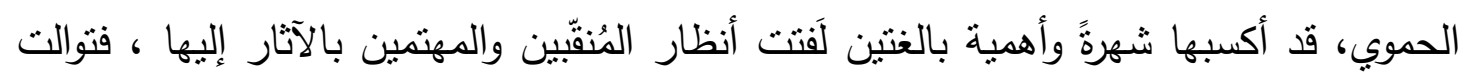

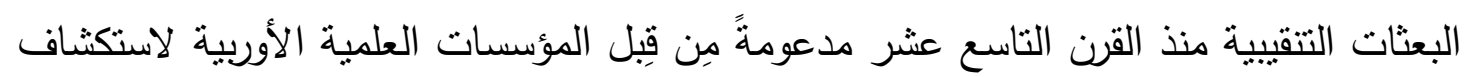
هذه المدينة العظيمة. وقد مرّت عمليات الاستكثاف والتتقيب في مدينة نينوى الأثرية بعدد من المراحل فكانت

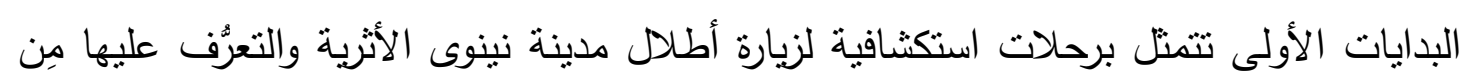

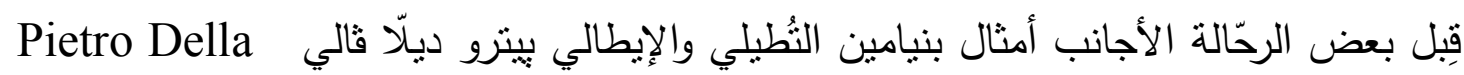


Valle، اعقبتها مرحلة تتقيبات القرن التاسع عشر (التتقيات غير العلمية أو العشوائية)، ثم تتقيات القرن العشرين (التتقيات العلمية) على يد البعثات الأجنبية، وبعد مغادرة هذه البعثات

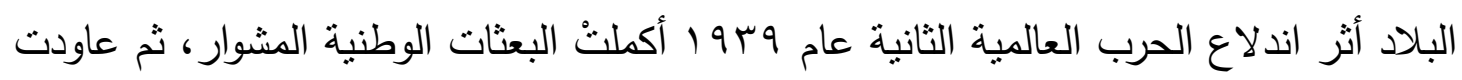

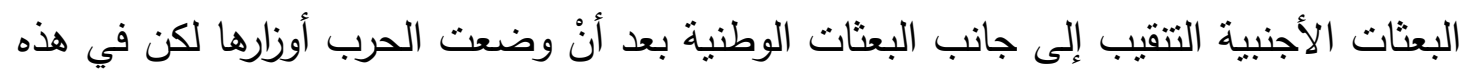
المرة كان التتقيب بنطاقٍ ضيِّق وتحت إثراف دائرة الآثار العراقية.

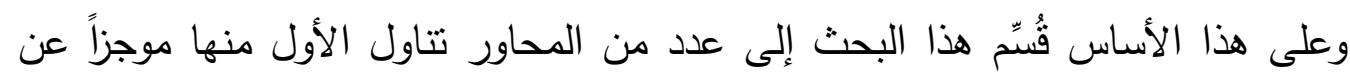

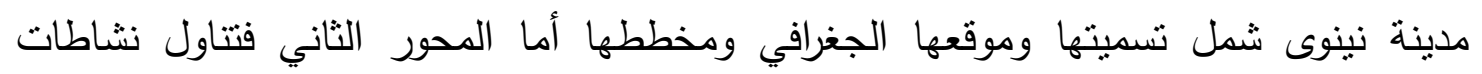

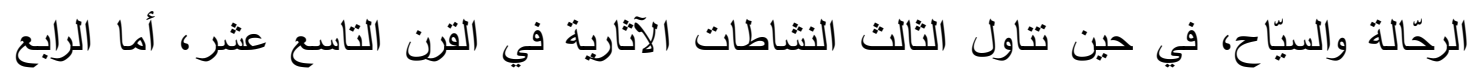
فتتاول طور التنقيات العلمية في القرن العشرين على يد البعثات الأجنبية فالوطنية.

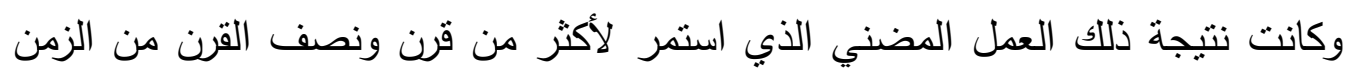

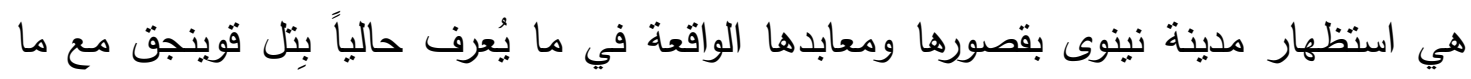

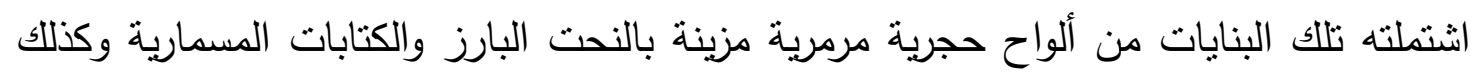
آلاف من الألواح المسمارية فضلاً عن استظهار اجزاء كبيرة من السورَين المحيطين بالمدينة:

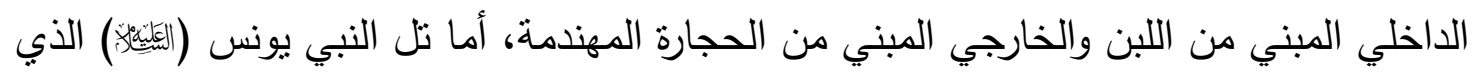

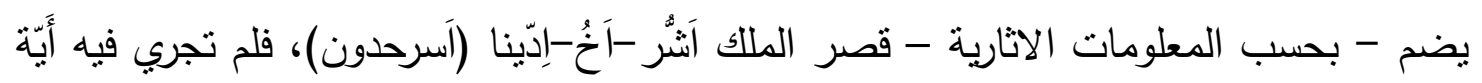

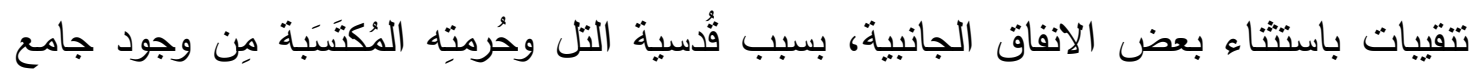

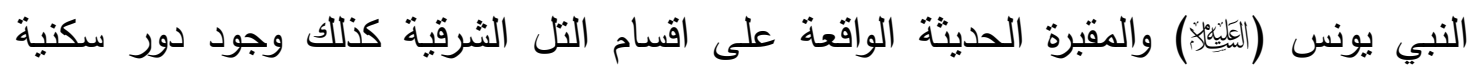

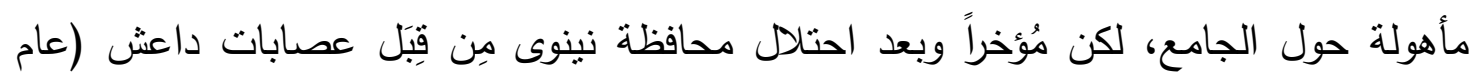

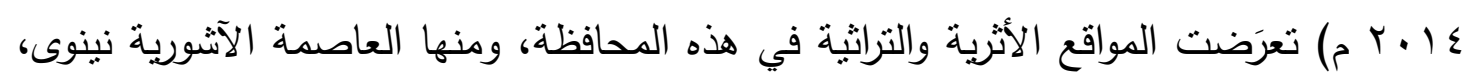

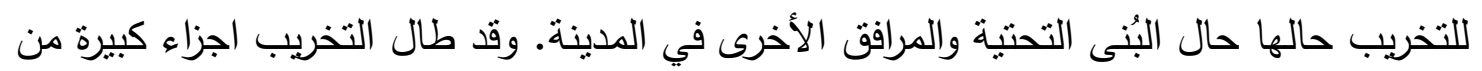

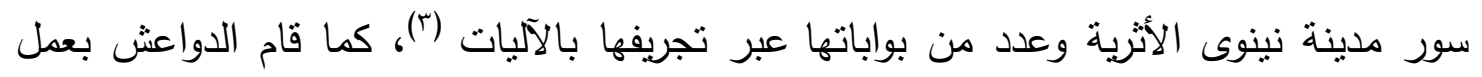

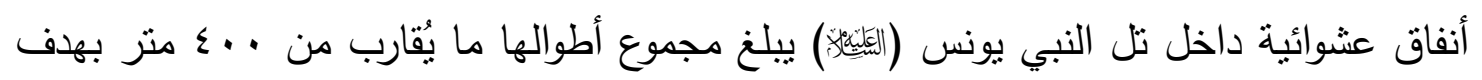

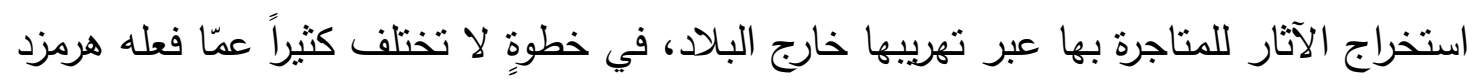

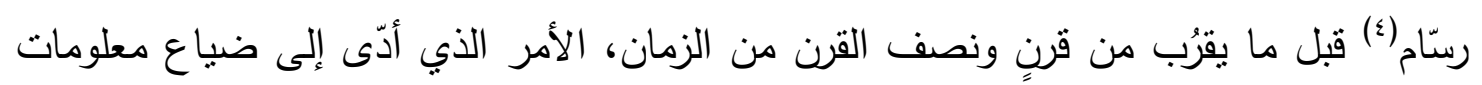
آثارية قيّيّة لا يمكن استرجاعها أو حتى تعويض فيض فيمتها الآثارية. 


\section{مدينة نينوى}

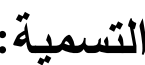

وَرََّ اسم مدينة نينوى في النصوص المسمارية بصِيٍَ مقطعةٍٍ عِدّة، أكثرها شيوعاً

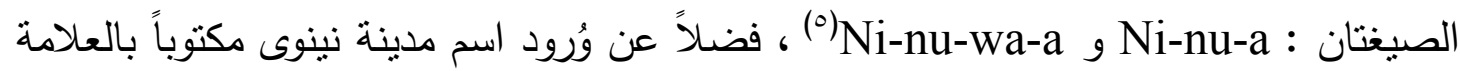

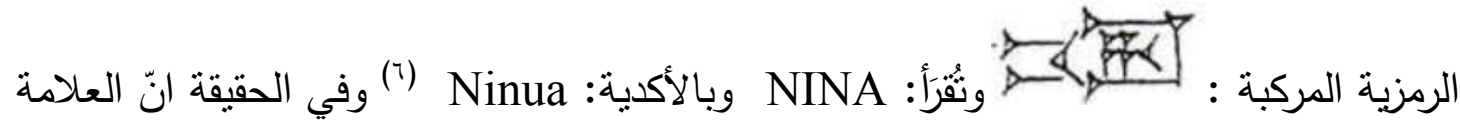
المسمارية المذكورة مؤلفة من علامنين مسماريتين، هما:

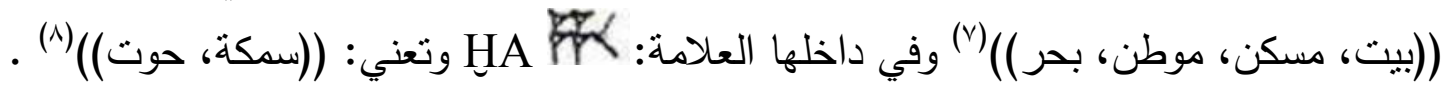

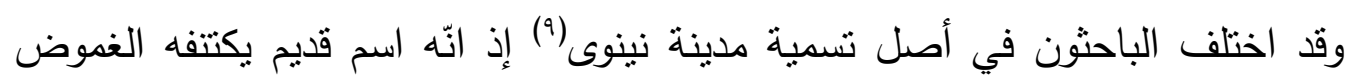

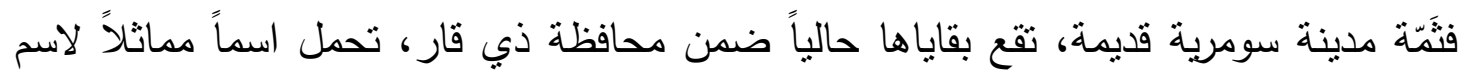

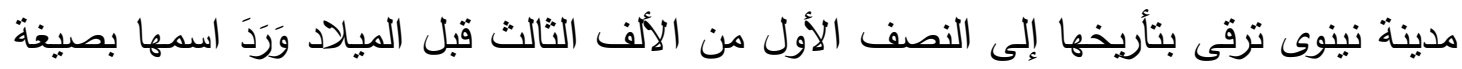

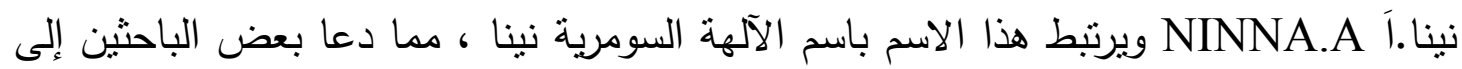

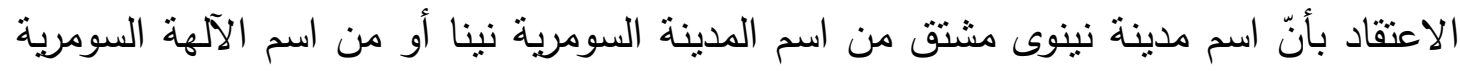

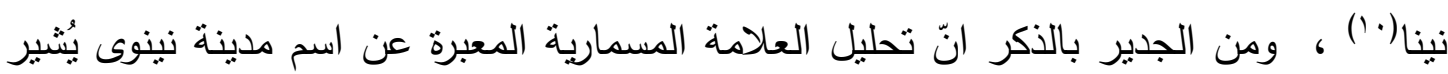

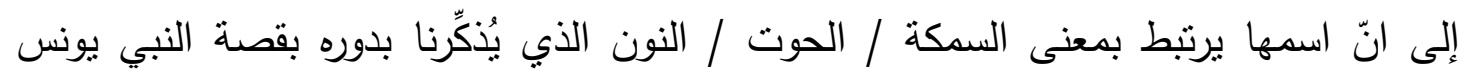

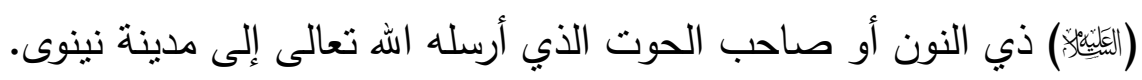

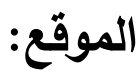

تقع مدينة نبنوى على الجانب الثرقي من نهر دجلة قُبالة مدينة الموصل القديمة، وكانت

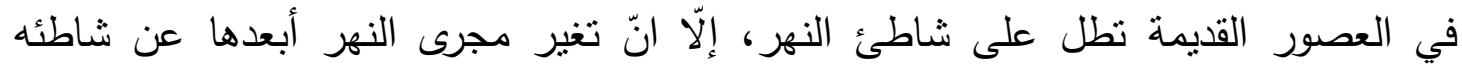
بمسافة تزيد على الكيلو متر في الوقت الحاضر ويخترق المدينة نهر الخوصر من جهنها

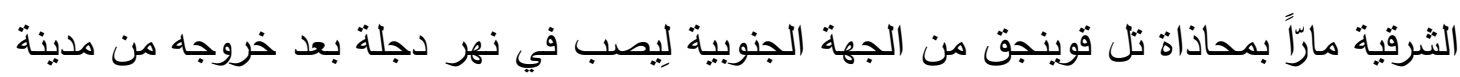

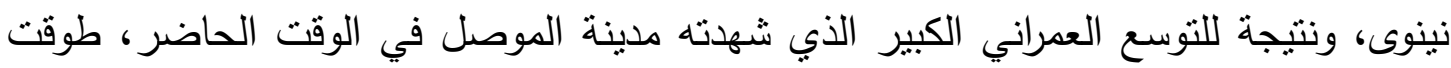

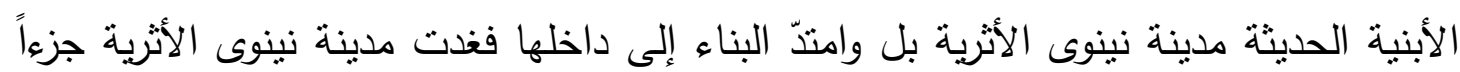
من مدينة الموصل الحديثة(") ، ويحد مدينة نينوى الأثرية من الجهة الثمالية مدينتان آثوريتان الثنان

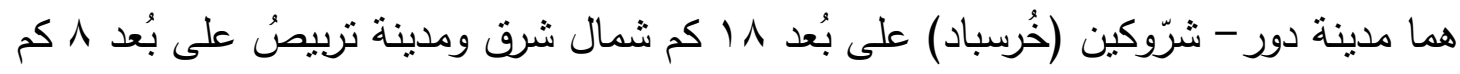

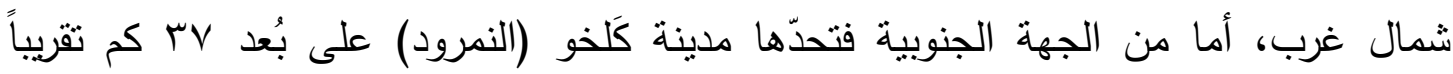

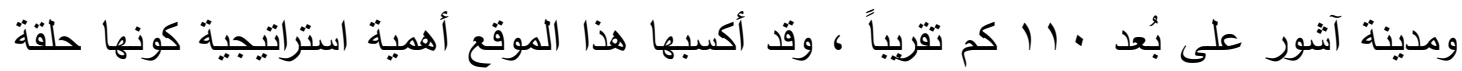
وصل بين تلك العواصم والمدن الآتشورية بسبب وقوعها على الطريق الرابط بين تلك الددن. 


\section{مخطط المدينة:}

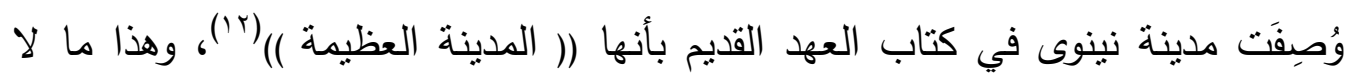

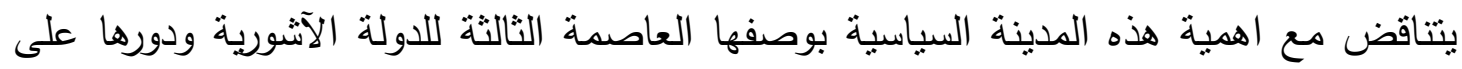

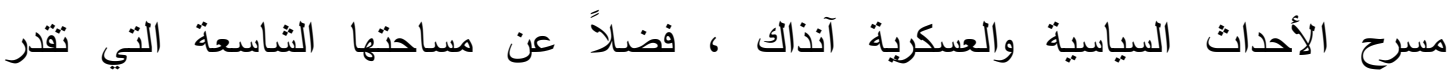

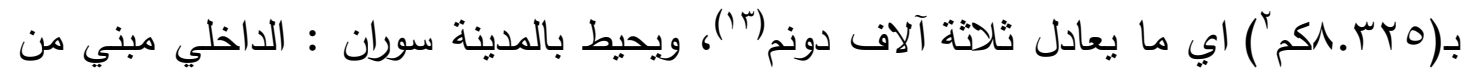

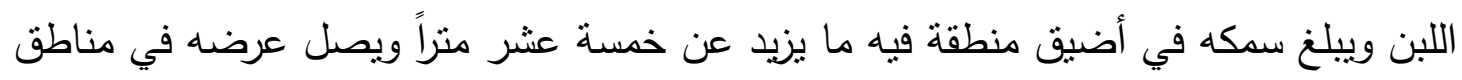

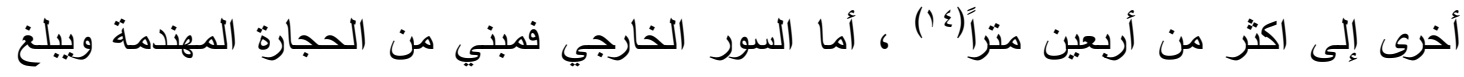

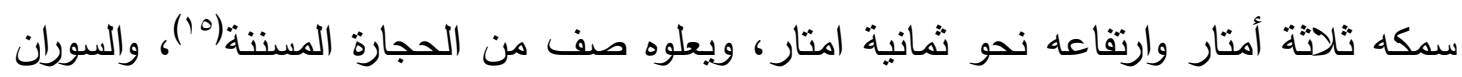

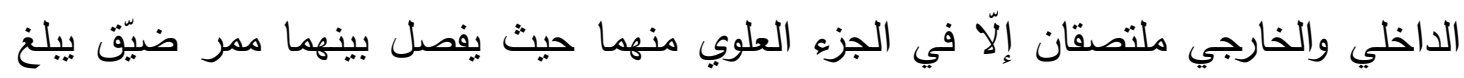

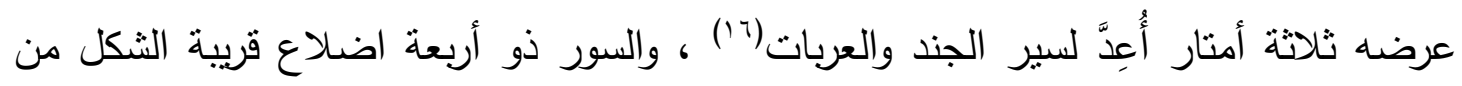

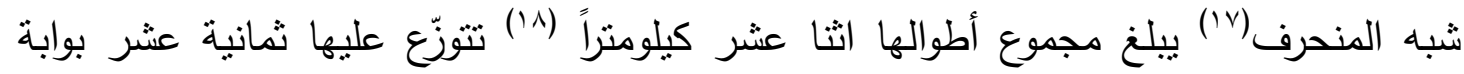

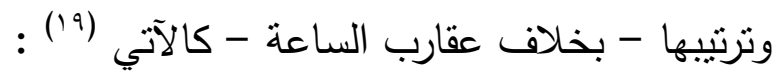

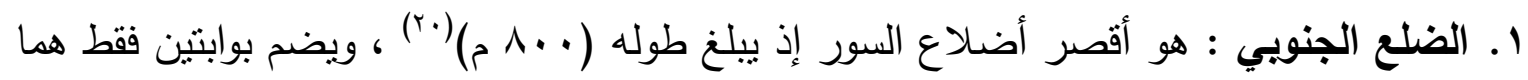

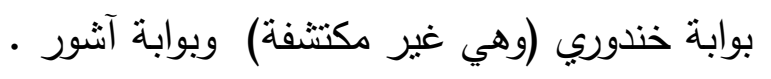

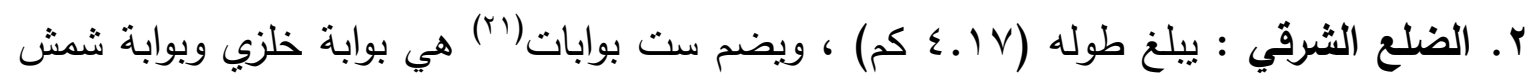

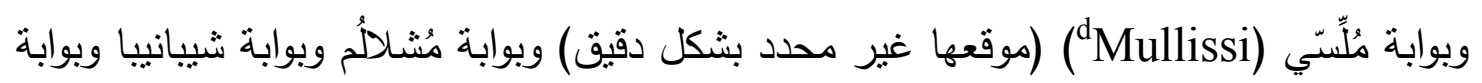

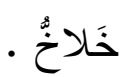

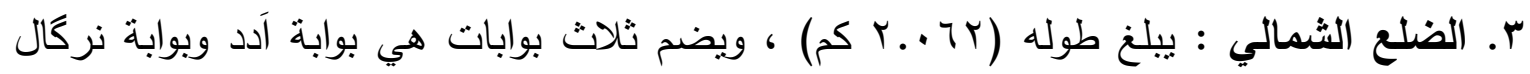
وبوابة سين (rr)

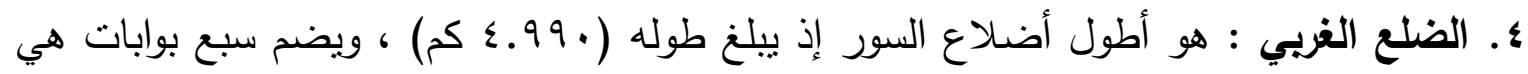

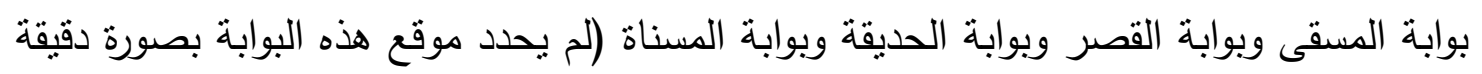

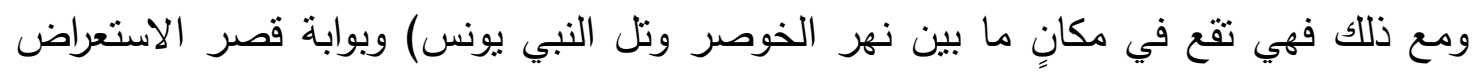

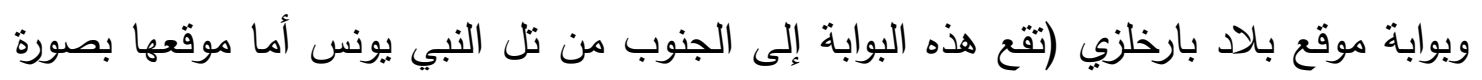

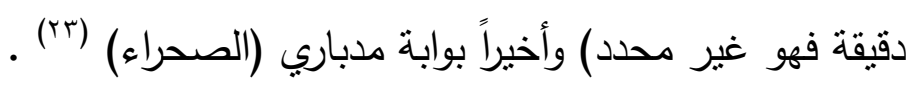

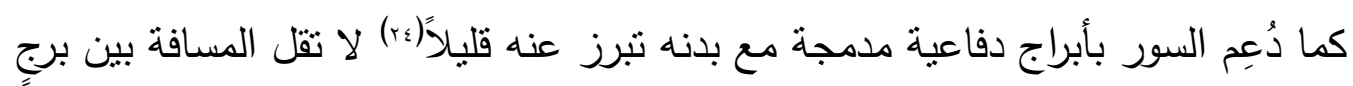

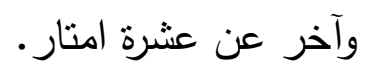

أما قصور المدينة ومعابدها فقد شيدت في منطقتين رئيستنن تؤلفان حالياً تل قوينجق وتل

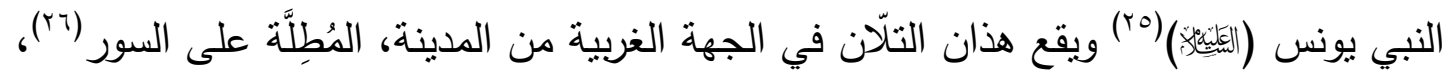

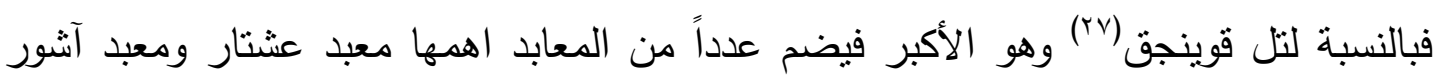


ومعبد كدموري ومعبد سيبيتي ومعبد نابو ومعبد سين وشمش ومعبد أدد، كما يضم التل عدداً من القصور اهمها القصر الجنوبي الغربي ( قصر سنحاريب) والقصر الثمالي (قصر آشور -

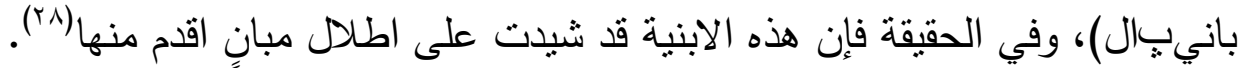

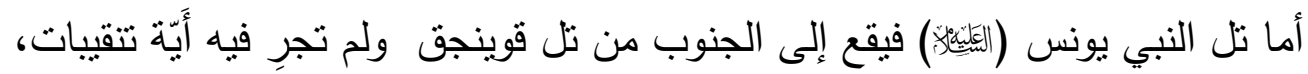
باستثناء بعض الانفاق الجانبية، بسبب وجود جامع النبي يونس (الِّلئهِّ) عليه، فضلاً عن وجود

مقبرة حديثة واسعة على اقسام التل الثرقية ووجود دور سكنية مأهولة حول الجامع(؟r). التنقيب في مدينة نينوى

اكتسبت مدينة نينوى شهرة واهمية بالغتين بسبب وُرود ذكرها في الكتب المقدة مثل

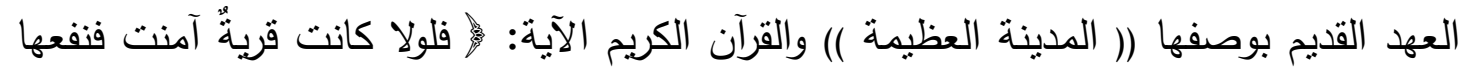

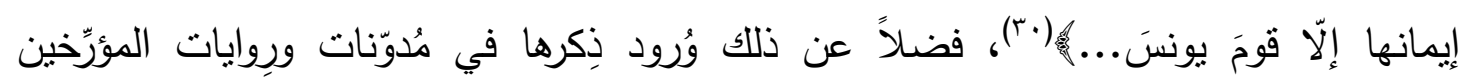

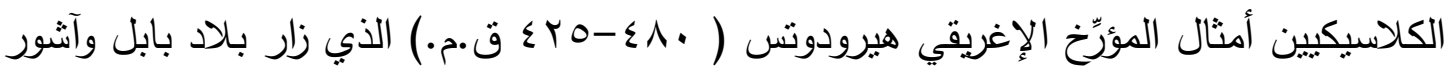

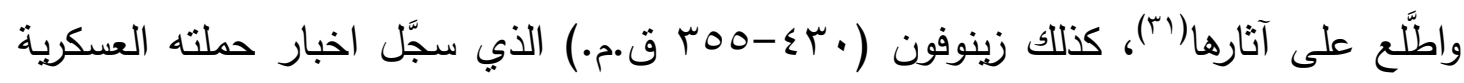
وما صادفه من مشاهدات ووصف للمدن في بلاد الرافدين ومنها مدينة نينوى التي لم يذكرها باسمها بل ذكر بقايا حصون وأسوار ضخمة بالقرب من بلدة ذكرها باسم مسيلا بلا بلان

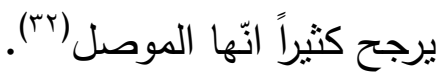
كل ذلك كان عامل تحفيز أدّى إلى اتِّجاه بعض الرحّالة والسيّّاح لزيارة مدينة نينوى فكان

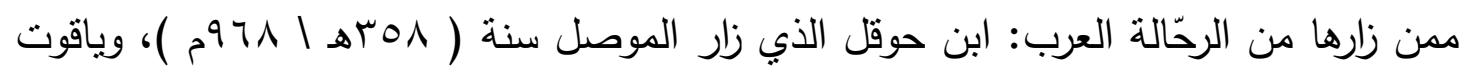

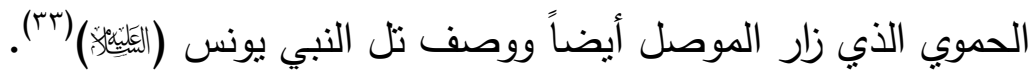

أما الرحّالة الأجانب فأول من زار مدينة الموصل منهم هو بنيامين النُطيلي Benjamin of Tudela مدينة نينوى الاثرية بـ( آشور العظيمة ) مُعتقداً بأنها مدينة آشور ، كما قدر طول سورها بمبالغةٍ

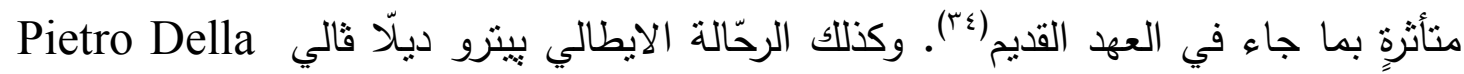
Valle نينوى الأثرية ودرس اطلالها وجلب معه إلى أوربا بعض القطع الأثرية فكانت في الواقع من أولى المجموعات الأثرية من بلاد الثرق التي وصلت إلى أوربا. وفي عام VA ام وصل إلى الموصل كل من الرحالتين بوشامٍ Beauchamp الفرنسي ومِكنان Mignan الإنكليزي وفحصا سويةً أطلال مدينة نينوى، كما زار مدينة نينوى الأثرية عدد من الرحّالة الأوربيين من بينهم الراهب الايطالي دومنيكو لانزا والدنماركي كريستين نيبيور الذي وصل مدينة الموصل في 


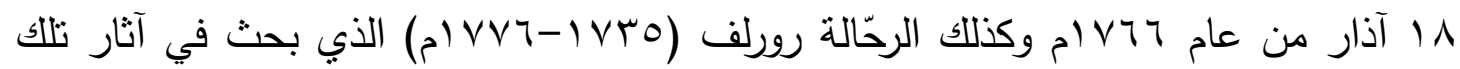

المدينة بعد ان استطلع تلولها من على قمة تل قوينجق (ror).

وقد أثنارت كتابات هؤلاء الرحّالة هي الأخرى من جاء بعدهم بهدف استكثاف المنطقة والتعرف على آثارها، فنشطت المؤسسات العلمية الأوربية في القرن التاسع عشر فأرسلت بعثاتها الاستكثافية، ومنذ ذلك الحين بدأت العناية بالآثار واستكثافها واقتتائها، فتوالت البعثات التتقيبية الواحدة تِلوَ الأخرى للتنقيب في مدينة نينوى الأثرية(َr) إلّا انّ التتقيب عن الآثار في البدء كان أقرب إلى النبش منه إلى التنقيب العلمي. وبهذا الصدد وقبل الثروع في موضوع تاريخ التنقيات في مدينة نينوى لابد لنا من تعريف علم الآثار الذي هو "مجموعة التنقيات الفنية الميدانية والدراسات والابحاث العلمية والانسانية التي تتتاول الآثار المادية والفكرية لنشاط الانسان القديم عن طريق استظهار تلاك الآثار والكثف عنها بوساطة وسائل فنية وتقنية وفق أُسس علمية ضمن اطار أكاديمي ليتم وصفها وتسجيلها وصبانتها وعرضها، فضلاً عن دراستها وتحليلها واستتباط المعلومات منها حول ماضي الإنسانية ومراحل تطورها"(rV"). وانطلاقاً من هذا التعريف يتوجب علينا التمييز بين المراحل التي مرت بها التتقيات الآثارية في مدينة نينوى، ففي البدء كان التتقيب عن الآثار يتسم بالنبش، والغاية منه الحصول

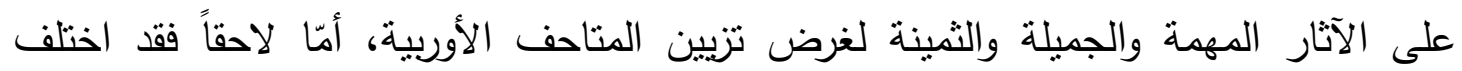
الأمر، إذ ازداد الوعي الآثاري لدى المنقبين عن الآثار، فأخذوا يوَثِّون القطع الأثرية وأماكن العثور عليها والطبقات الاثرية التي تعود اليها والاهتمام بأدق التفاصيل والمعلومات التي تخصها. وهكذا فإنّ التقيب في مدينة نينوى قد مرّ بمراحل تطورية ، وكالآتي :

\section{تنقيبات القرن التاسع عشر (التنقيبات غير العلمية):}

بعد توالي زيارات الرحّالة الأجانب إلى مدن العراق الأثرية بصورة عامة ومدينة نينوى بصورة خاصة، ذاع صيت هذه المدينة في الاوساط الاوربية فلاقت شهرة كبيرة كان لها الأثر الواضح في استقطاب الباحثين والمهتمين بالآثار فشرعت الجمعيات والمؤسسات العلمية الاوربية في القرن التاسع عثر بإرسال بعثاتها التتقيبية والاستكثافية ودعمها ، ولاسيما المؤسسات البريطانية والفرنسية، فكانت البداية الفعلية للتنقيات في مدينة نينوى الأثرية تعود إلى عام • r 1 ا حيث أجرى القنصل البريطاني كلوديوس جيمس ريج Claudius James Rich بعض الحفائر المتتاثزة في تل قوينجق(^^)، وكان هذا المنقب يشغل منصب المقيم البريطاني لشركة الهند الثرقية في بغداد، إذ اتجّه إلى شمال العراق في رحلة استكثافية فزار مدينة الموصل وتفحّص تل النبي يونس (الِّلنهّ) وتل قوينجق فحصاً دقيقاً وأجرى تحريات في المدينة الأثرية 
فتمكن من الحصول على مجموعة من القطع الأثرية مثل الأختام الاسطوانية والنصوص

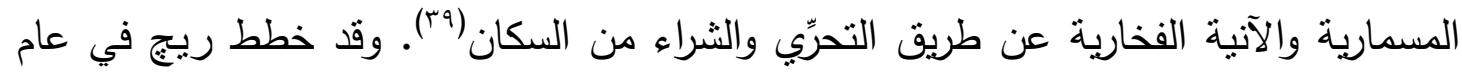
• ب 1 ا للقيام بعمل آثاري في نينوى إلّا انّه أصيب بمرض الكوليرا الذي أودى بحياته في تلك السنة، فآلت جميع مقتتياته، ومنها كتبه المخطوطة والقطع الأثرية، إلى المتحف البريطاني (•؛). وقد كان لتقارير ريج ومذكراته المنشورة عن مدينة نينوى الأثرية(اء) الأثر الكبير في لفت أنظار الحكومات الأوربية، خصوصاً بريطانيا وفرنسا إلى الآثار الموجودة في منطقة الموصل، وعلى ملى

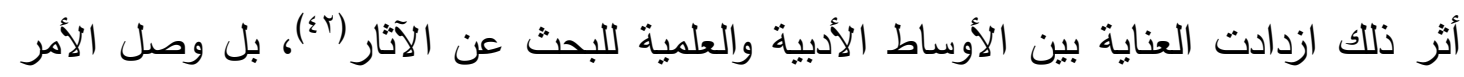
بفرنسا أنْ فتحت لها قنصلية في الموصل عُيِّن فيها بول إِيل بونا Paul Emil Botta قنصلاً عام 1 1 1 على أثز توصية من المستشرق يوليوس موهل Julius Mohl سكرتير الجمعية

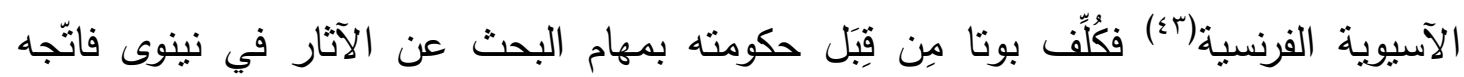

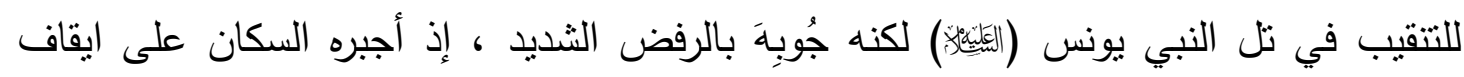
عمله بسبب قدسية التل ووجود مقبرة عليه، فانتقل إلى تل قوينجق واختار عِدَّة نقاط للتنقيب فيه

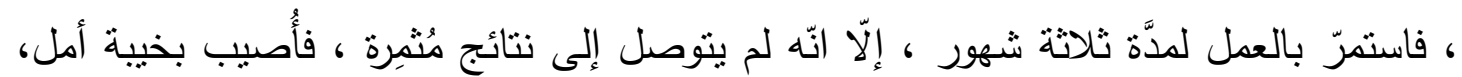
وفي هذه الأثتاء عَلمَ بوتا من الاهالي بوجود موقع أثزي في قرية خرسباد التي تقع على مسافة

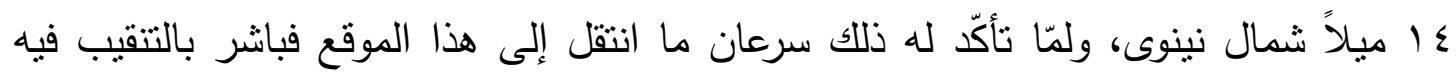
حيث عثر على آثار عظيمة جُلّها من المنحوتات الحجرية التي كانت تزين الاقسام الداخلية من

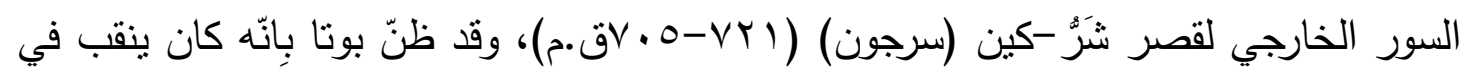

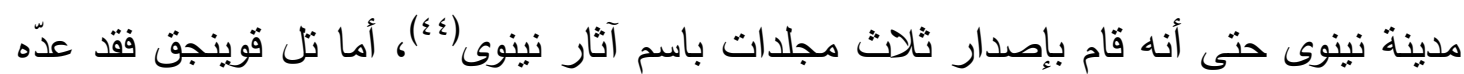

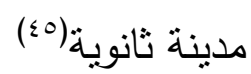

إلّا انّ نجاحات بوتا لم تدم بعد أن فوجئ بقرار من حكومته بإغلاق قنصليتها في الموصل، وبغياب فرنسا عن عمليات التتقيب عن الآثار اغتتمت بربطانيا الفرصة حيث كان اوستن هنري لايارد Austen Henry Layard الذي اصبح قنصلها في الموصل بعدئذ،

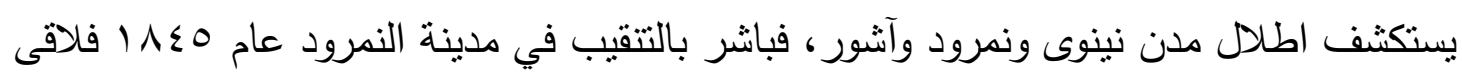

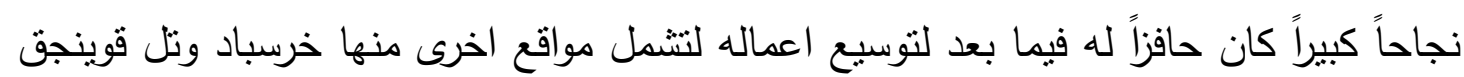

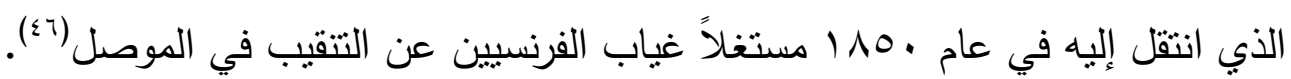
وفي عام 1101 إد عاد لايارد إلى بريطانيا ناركاً المواقع الأثربة لمساعده هرمزد رسّام وهو نصراني من سكنة الموصل كان ولاؤهُ للحكومة البريطانية( (ی). Henry بعد ان اعتزل لايارد العمل خلفه في النشاط الاثري الانكليزي هنري رولنصون

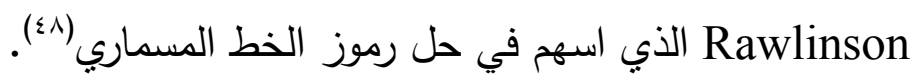


وقد شهد عام 110r تنافساً شديداً بين المنقبين البريطانيين والفرنسيين وذلك بعد اعادة فتح القتصلية الفرنسية في الموصل واستثئن التتقيب في المدن الآثورية وتتسييها الآثاري فكتور يلاس Victor Place لهذه المهمة عام 1101 ليحل محل بوتا في الموصل، ومن صور التنافس بين الفريقين ان جرى الاتفاق على تقاسم تل قوينجق بين فريقي هاتين الدولتين، فأصبح

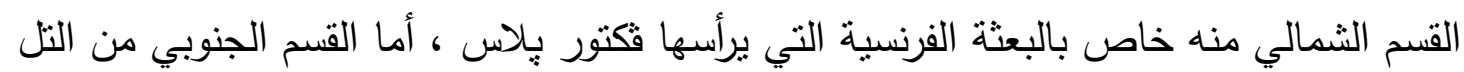

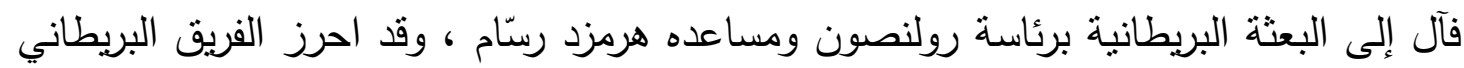

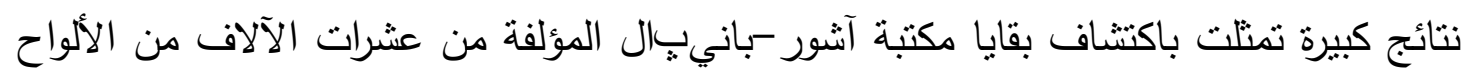

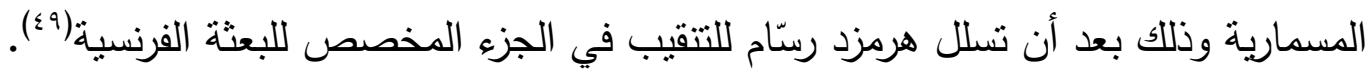

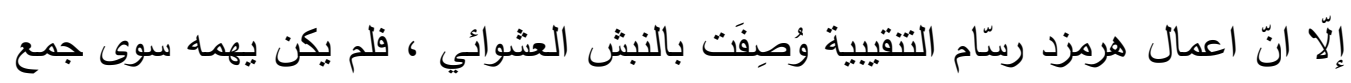

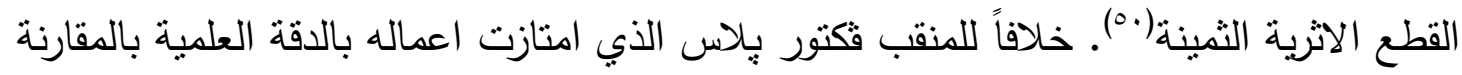

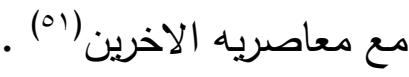
وفي عام 1101 اصدرت الحكومة الفرنسية اوامرها إلى فكتور بِالاس بإيقاف اعمال

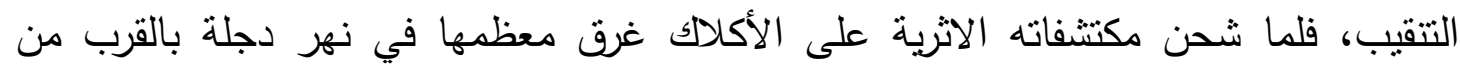

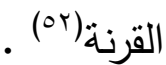
وهكذا انفردت بريطانيا مرة أخرى بالعمل الآثاري بعد عودة فكتور بِلاس إلى فرنسا فأكمل

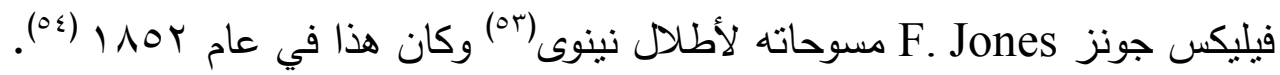

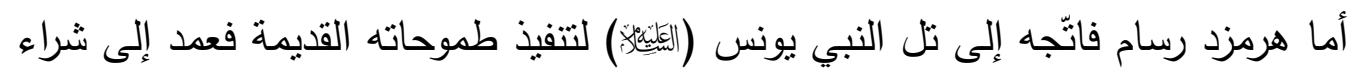

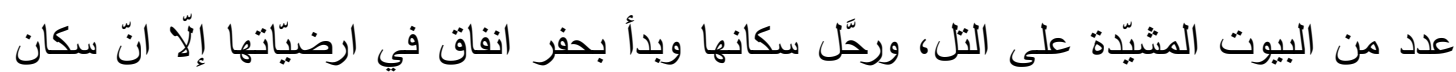

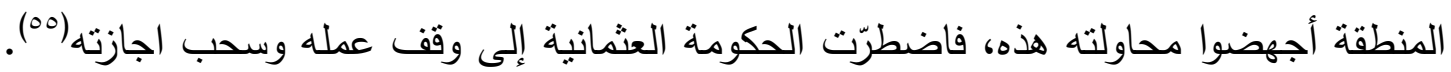

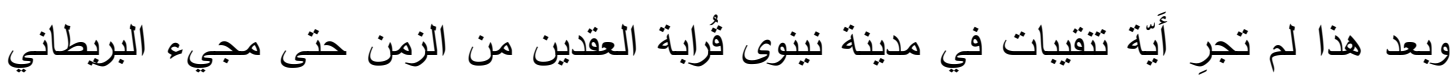

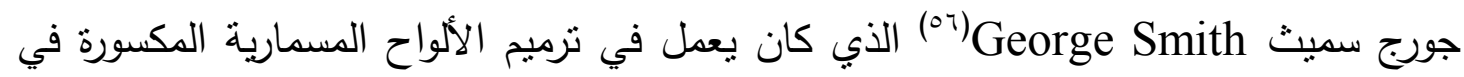
المتحف البريطاني ، وفي عام AVT نجح سميث في تشخيص إحدى الألواح العائدة لملحمة كلكامش والتي تبين انها تروي قصة الطوفان ، وسرعان ما اعلن عن اكتثافه امام جمعية الآثار

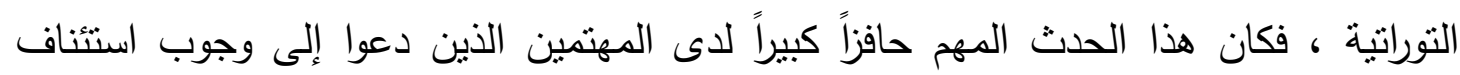

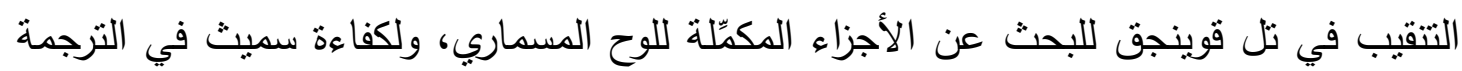

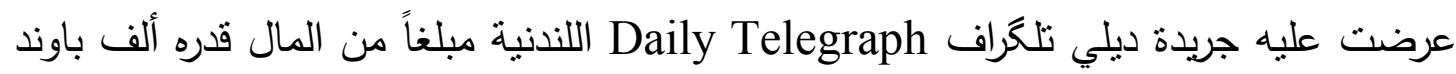

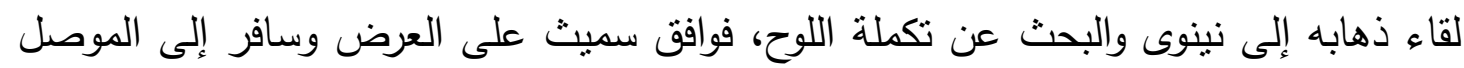
عام INVT ، فلم تمضي سوى سبعة ايام للتنقيب في تل قوينجق حتى عثر على على اللوح المفقود،

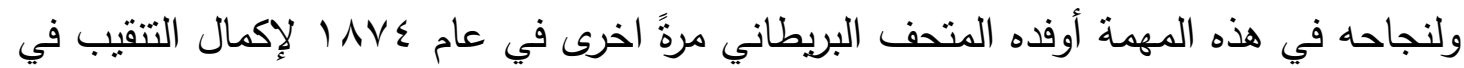

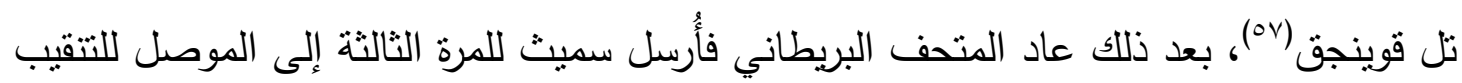


في تل قوينجق، وبعد اكمال مهامه وفي طريق عودته إلى انكلترا مات بالقرب من مدينة حلب

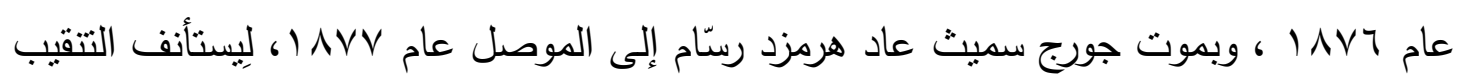

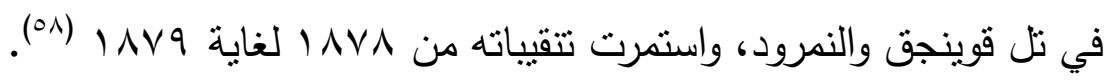

\section{تنقيبات القرن العشرين ( التنقيبات العلمية ):}

على الرغم مِن انّ الألمان لم يجروا أَيّة اعمال تتقيبية في مدينة نينوى الأثرية (موضوع البحث)، إلّا انّه لابد من ذكر انّ تتقيبات البعثات الألمانية في مدينة بابل الأثرية ( في المدة

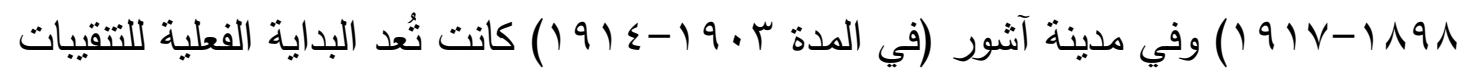
العلمية في العراق بصورة عامة، وعلى هذا الأساس صُنِّت تتقيبات القرن العشرين في العراق بالعلمية مقارنة بسابقتها (ه). أما في مدينة نينوى الاثرية، فقي مطلع القرن العشرين وتحديداً في عام 19 الـ عمل

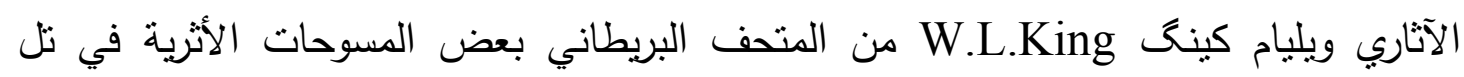
قوينجق اعقبها اعمال تتقيب في عامي r 19.9 و ع. 19 شملت اجزاء مختلفة من التل نفسه تركزت في قصر سنحاريب ( الجنوبي الغربي ) وقصر آشور -باني:ال ( الثمالي )(.٪).

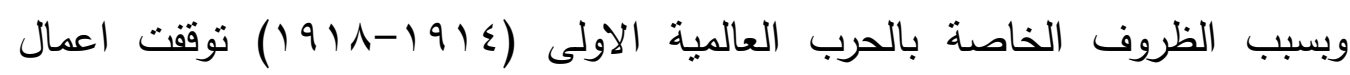
التتقيب في العراق لِنُشتأنف مرة اخرى -عقب انتهاء الحرب- على يد عدد من الضباط Campell الإنكليز، أبرزهم ليونارد وولي Leonard Woolley و كامِل توميسون وماكس ملوان M. Mallowan ، ، جيث ترأس وولي بعثة بريطانية - امريكية للتتقيب في موقع مدينة أور وحقق نجاحاً باهراً، أما نوميسون فقد انتقل إلى مدينة نينوى بعد ان

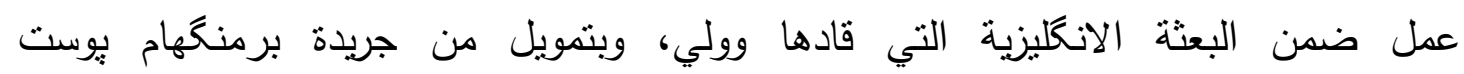
Cبirmngham Post ما إذا كانت هنالك طبقات سكنى لعصور ما قبل التاريخ تحت الطبقات الآتورية للحصول على أدلّة تخص علاقة منطقة نينوى بالطوفان، وكان يساعد تومِّون في ذلك كُلاً من هتشنسن Hamilton وهاملتون Hutchinson واستمر العمل بحفر الخندق لمدة سبعة اسابيع حتى تم الوصول إلى قاع الموقع (الارض البكر) الذي قدر تومبسون عمقه بمائة قدم (اي ما يقارب rV منز )، منها اثتنان وسبعون قدماً تعود ازمنتها لعصور ما قبل التاريخ ، تبدأ من عصر (نينوى () في القعر وتتنهي بـ(نينوى 0) في

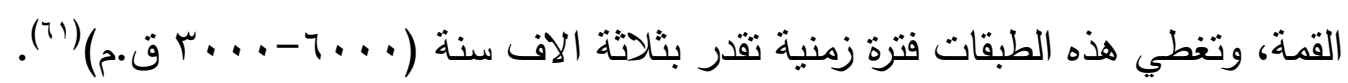


وبعد هذا لم تجرِ أَيّة تنقيبات أجنبية في مدينة نينوى حتى عام 19NV حيث نقبّت بعثة

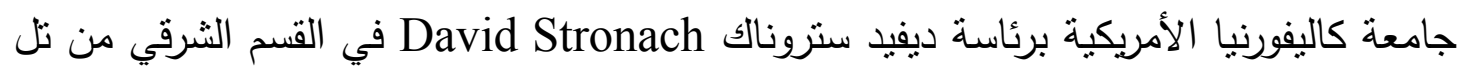

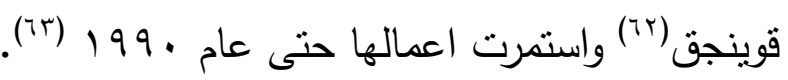

\section{التنقيبات الوطنية :}

بعد تأسيس دائرة الآثار في العراق سنة ـ ب ا9 أشرّع أول قانون لحماية الآثار العراقية في

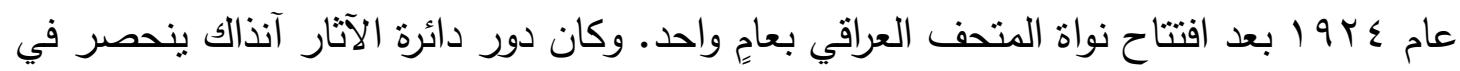

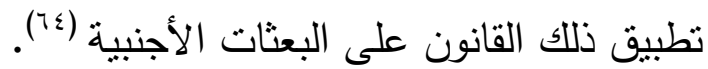

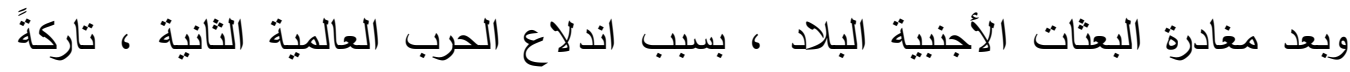

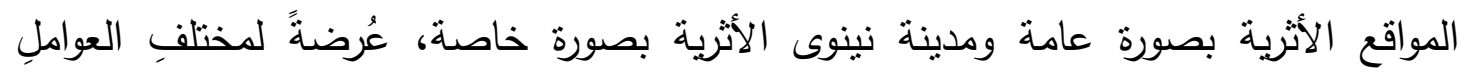

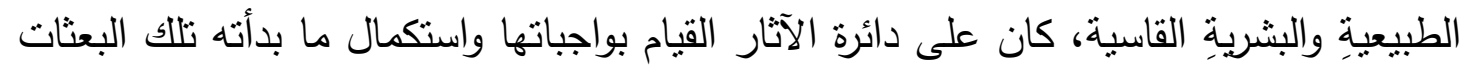

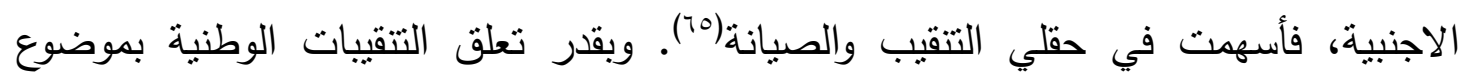

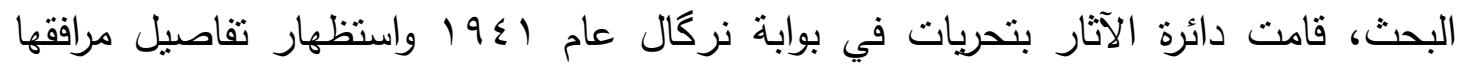

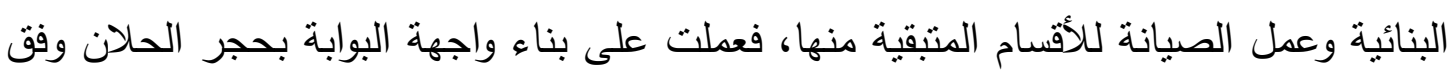

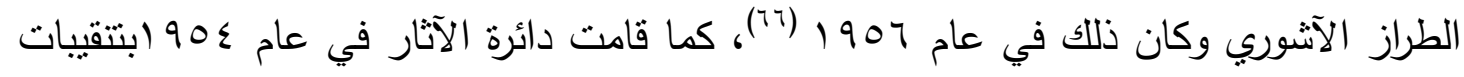

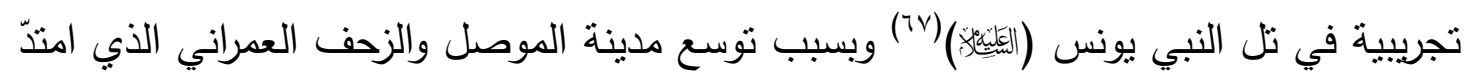

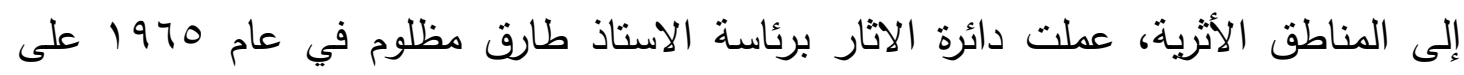

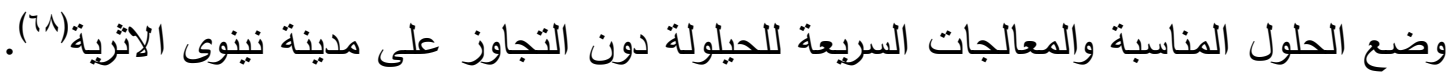

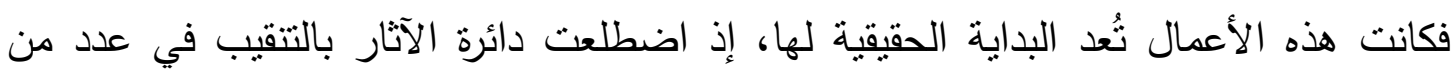

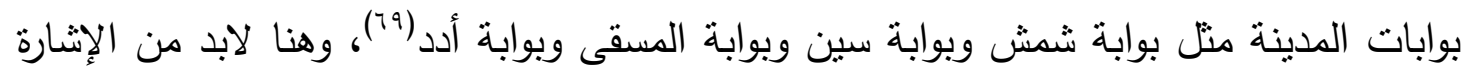
إلى دور جامعة الموصل في التتقيب في بوابة أدد وصيانتها واستظهار اجزاء من سور المدينة

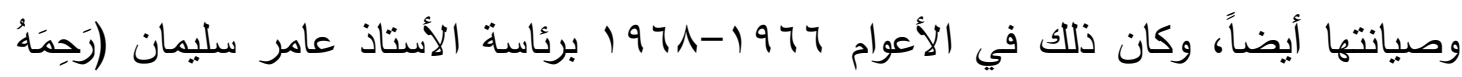
( اله)

ومؤخراً باشرت بِعثة جامعة الموصل - كلية الآثار برئاسة الأستاذ علي ياسين الجبوري

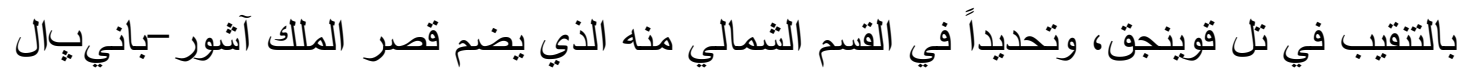

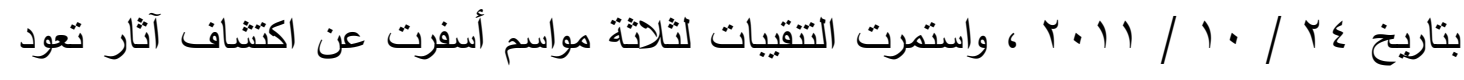

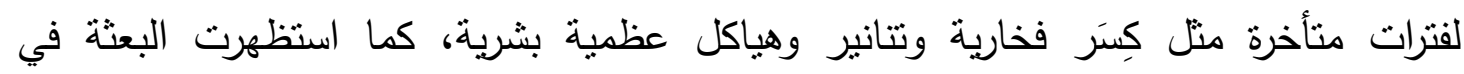
الطبقات الأدنى آثاراً آنشورية كجدران حجرية وأرضيّات حجرية، وعثرت على على كِسَر فخارية فضلاً

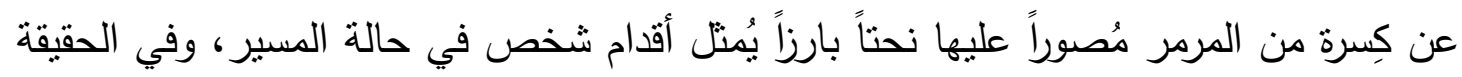


أن هذه الكِسرة تمنل الجزء السفلي للوح كبير من المرمر عليه مشهداً متكاملاً يُزين إحدى

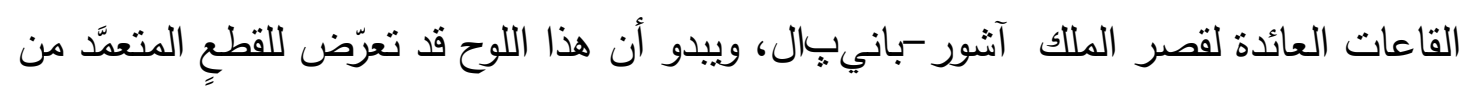
قبل دُنقبّوا المتحف البربطاني، الذين نقبَّوا خلال القرن التاسع عشر، ليسهل حمله ونقله، غير

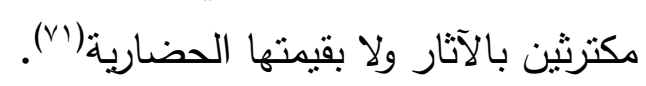

\section{الخاتمة والاستثتاجات}

خلصت هذه الدراسة الموسومة (تاريخ التتقيبات الأثرية في مدينة نينوى) إلى بعض

$$
\text { الاستتناجات التي من أهمها : }
$$

ا. لم يكن الهدف من التتقيب عن الآثار في البدء يتعلق بعلم الآثار وإنّما كان ذا أبعاد دينية وسياسية واقتصادية بِدليل انّ التتقيات اقتصرت على المدن التي ورد ذكرها في كتاب العهد القديم، يُضاف إلى ذلك انّ معظم المنقبين الذين أوفدوا للتقيب كانوا إما رجال دين أو سياسيين أو ضُبّاطاً في الجيش، كما انّ التتقيبات الأولى اتصفت بالنبش السريع الذي يهدف إلى جمع ما يمكن جمعه من الآثار النفيسة والجميلة لعرضها في المتاحف العالمية بهدف الكسب المادي دون الاكتراث بتوثيق التفاصبل العلمية، مثال على ذلك السباق الذي حدث بين الفريقين البربطاني والفرنسي للتتقيب في تل قوينجق مِن أجل جمع أكبر عدد ممكن من الآثار النفيسة من دون توثيق للمواضع التي عُثر فيها على تلك الآثار ولا الطبقات الأثربة العائدة لها الأمر الذي أدّى إلى ضياع معلومات آثارية قيّمة وإلى الأبد.

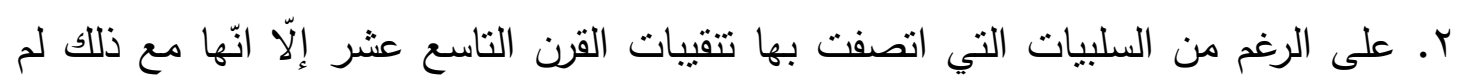
تكن تخلُ من بعض الإيجابيات مثل تتقيبات القنصل البربطاني كلوديوس جيمس ريج عام

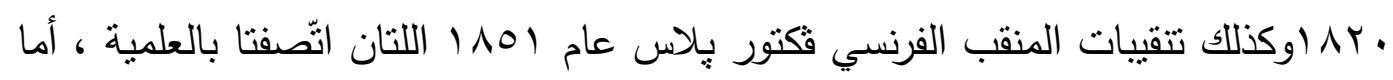
سبب وصف تتقيبات القرن التاسع عشر ، بصورة عامة ، بغير العلمية فيرجع لكون انّ علم الآثار آنذاك لم يكن قد تبلور بعد وانّ المنقبين الأوائل لم يكونوا آثاريين - كما ذكرنا سابقاً فلم يكونوا قد تعلّموا الأساليب العلمية في التتقيب ولهذا كانت تتقصهم الخبرة باسنثتاء البعض منهم ممن كان يتحلّى بمهارات ذاتية ، وهكذا فإنّ نتقيات القرن التاسع عشر غير العلمية تعد مرحلة طبيعية لنشوء علم الآثار وتطوره في تلاك الفترة . ז. لم تكن أعمال التتقيب في العراق بمعزلٍ عن مجرى الأحداث السياسية الجارية في العالم بصورة عامة والعراق بصورة خاصة ، إذ انّ سيطرة الدولة العثمانية على المنطقة أدّى إلى الى لهمي

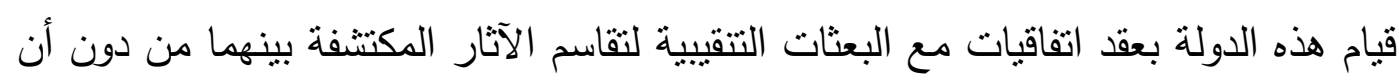

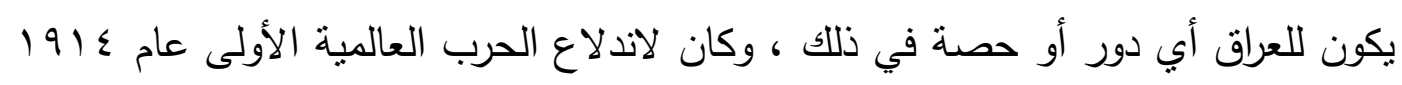


م أنزها في توقف أعمال التتقيب في العراق ، وبعد تقسيم المنطقة بموجب معاهدة سايكس-

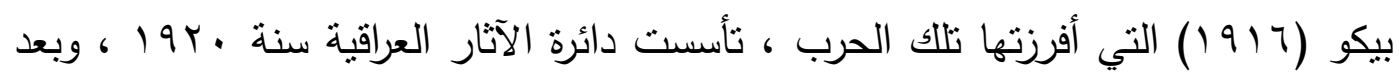

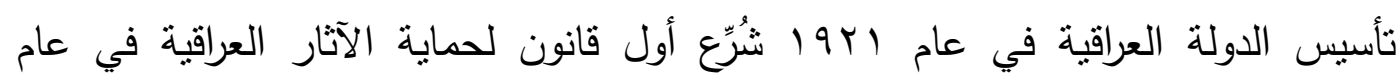
ع 9 1، وكان دور دائرة الآثار آنذاك ينحصر في تطبيق بنود ذلك القانون على البعثات

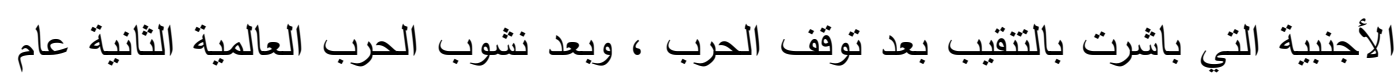

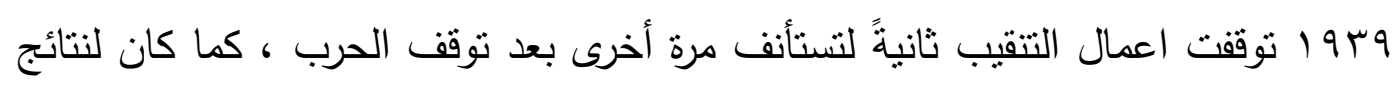

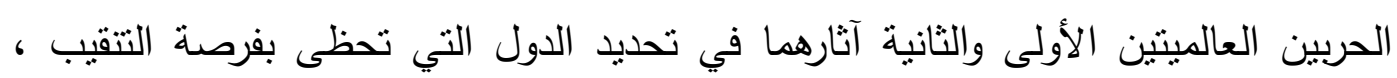

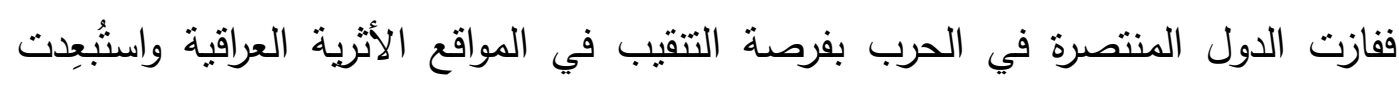

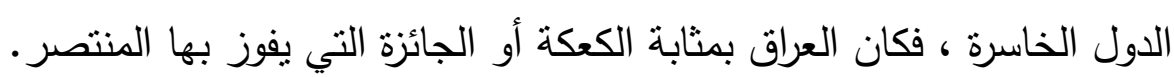

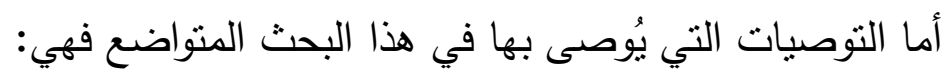
ا ـ إيقاف التجاوزات على المواقع الأثرية وإزالتها قدر الإمكان. r. ترميم الآثار التي تعرّضت للتخريب وصيانتها.

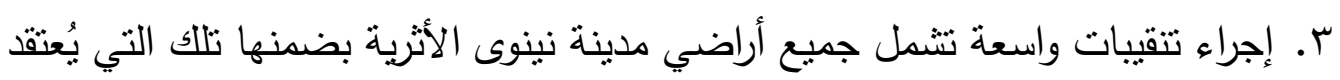

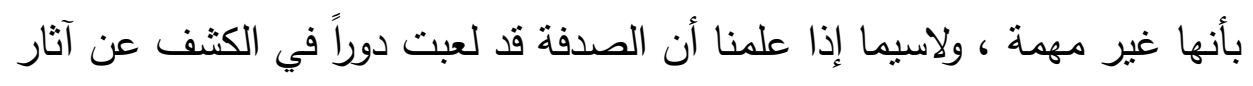

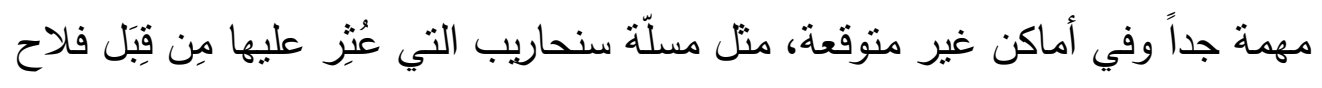

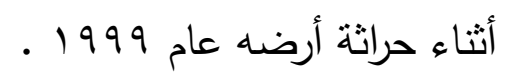
ء. الحد من تهريب الآثار خارج البلاد ومُلاحقة المُّاجرين بها بالتتسيق مع الثرطة الدولية. 


$$
\text { د. عبد الستار أحمد حسين }
$$

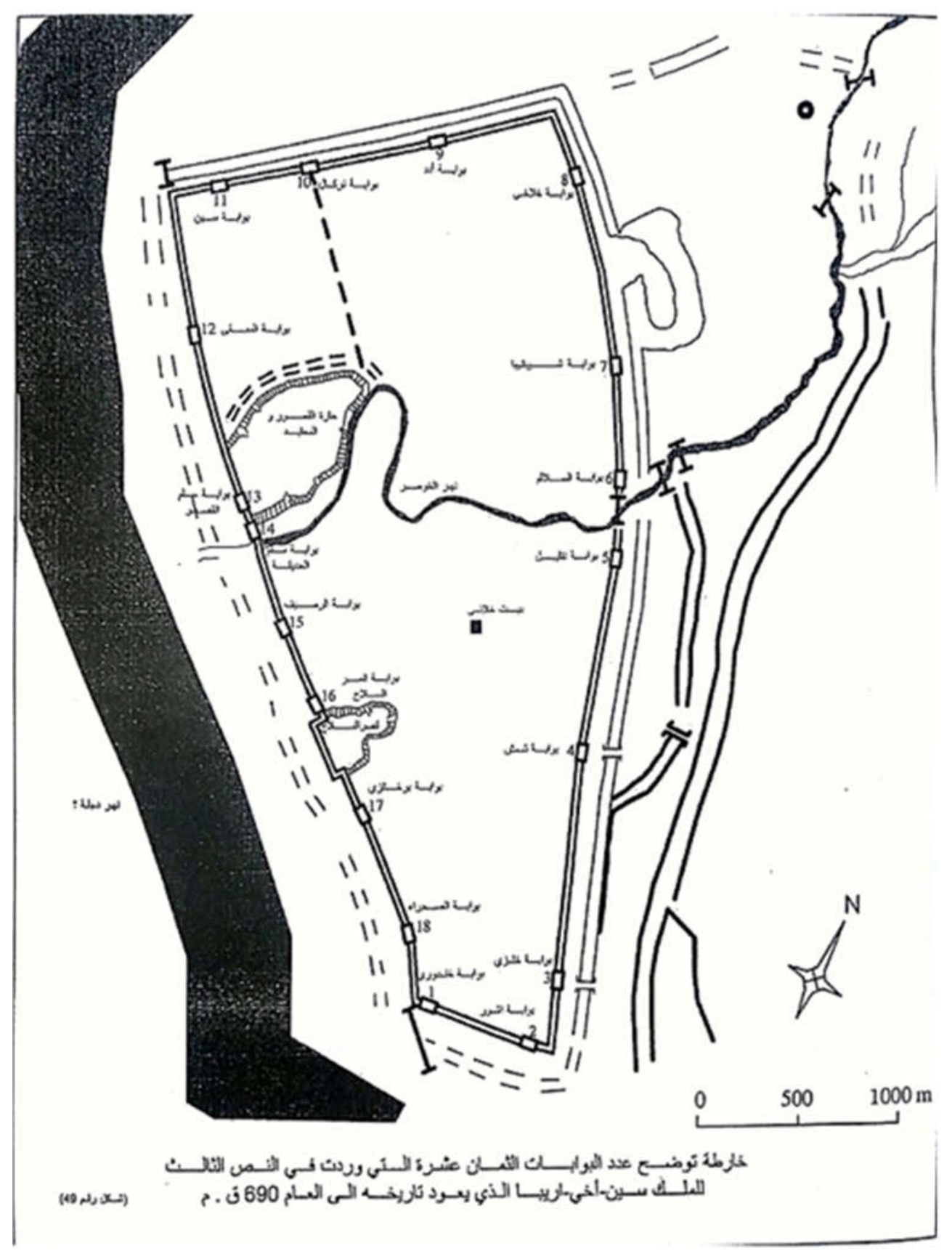

(1) (1) الشكل

مخطط عام لمدينة نينوى الأثرية

عن/سيف لقمان عبدالرزاق ، تخطيط مدينة نينوى في ضوء المصادر المسمارية والمكتشفات

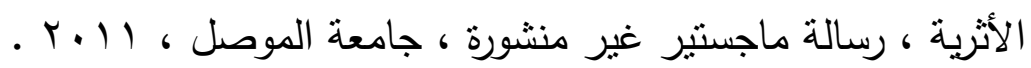


مجلة آثار الرافدين / المجلا ه / • r r r

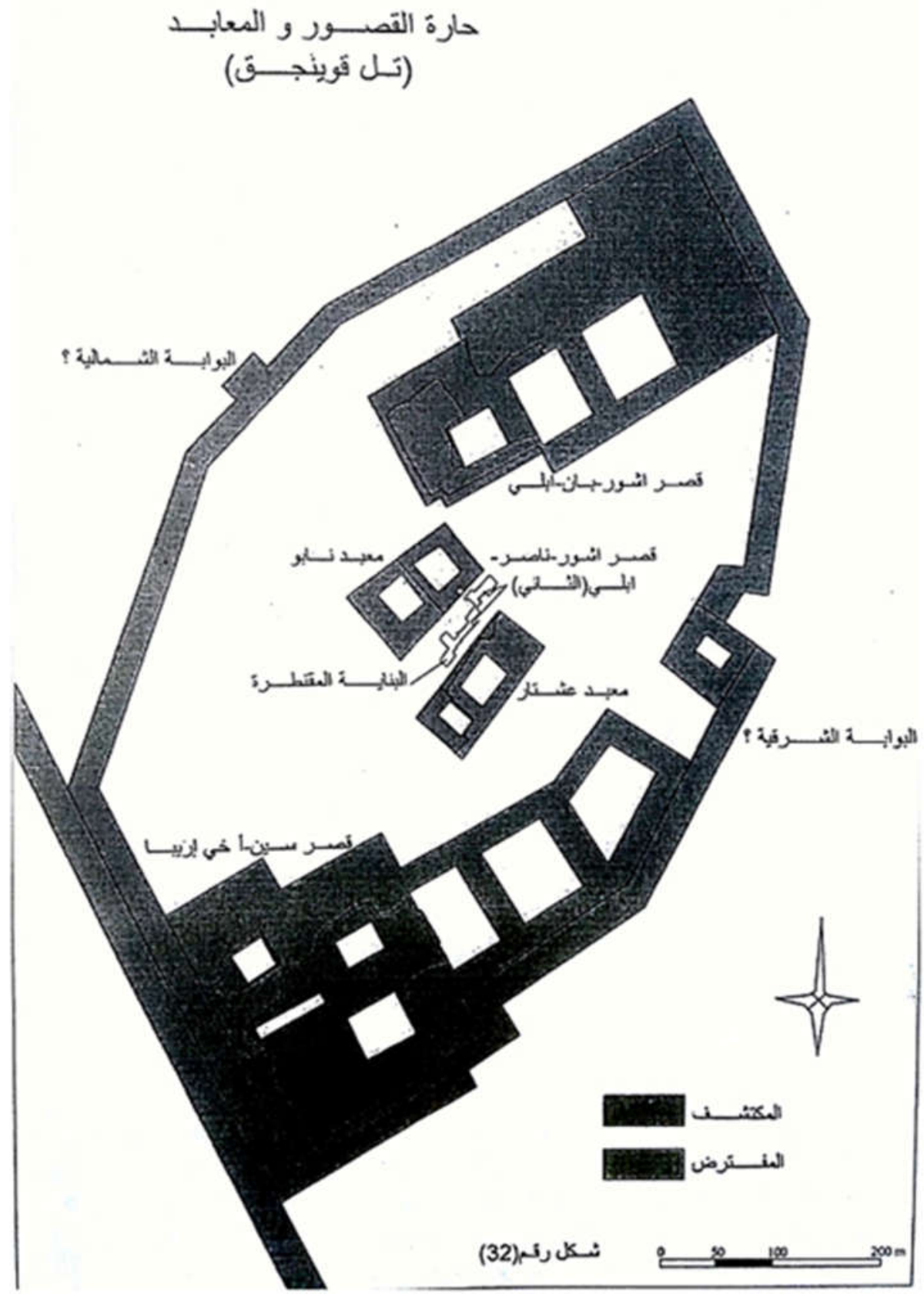

(r) الثكل

مخطط عام لتل قوينجق والأبنية التي يضمّها

عن/ سيف لقمان عبدالرزاق ، المصدر السابق . 


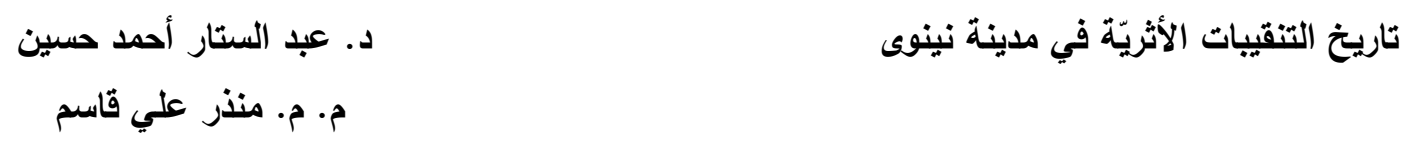

\begin{tabular}{|c|c|c|}
\hline Date & Excavator & Area \\
\hline xi. 1820 & C. J. Rich & K, NY, survey \\
\hline xii. 1842 -iii. 1843 & P.-E. Botta & K \\
\hline v. 1846 & A. H. Layard & SWP, Gate 10 \\
\hline v. $1846-$ v. 1847 & Guillois & K \\
\hline v-vii. 1847 & A. H. Layard & SWP \\
\hline vii. $1847^{-v i i . ~} 1849$ & H. J. Ross & SWP \\
\hline vii-x. 1849 & C. Rassam & SWP \\
\hline \multirow[t]{2}{*}{ x. 1849 -iv. 1851} & A. H. Layard & SWP \\
\hline & & $\begin{array}{l}\text { NY, town } \\
\text { Gates 4?, } 10\end{array}$ \\
\hline iv-v. 1851 & $\begin{array}{l}\text { C. Rassam/ } \\
\text { T. S. Bell }\end{array}$ & SWP \\
\hline$v-x \cdot 1851$ & C. Rassam & SWP, IT \\
\hline x. 1851 & H. Rawlinson & SWP \\
\hline x. $1851-$ iii. 1852 & C. Rassam & K, SWP \\
\hline iii-iv. 1852 & $\begin{array}{l}\text { H. Rawlinson/ } \\
\text { F. Jones }\end{array}$ & K, NY, survey \\
\hline iii-x. 1852 & C. D. Hodder & K, SWP \\
\hline x. 1852 -iv. 1853 & Hilmi Pasha & NY \\
\hline x. 1852 -iv. 1854 & H./C. Rassam & IT, NP, SWP \\
\hline iv. 1854 & W. Boutcher & NP \\
\hline v. 1854 -iii. 1855 & W. K. Loftus & K, NP, Gate 2? \\
\hline vii-ix. 1854 & C. Rassam & NP \\
\hline v-vi. 1873 & G. Smith & SWP, NP/NT, IT \\
\hline i-iii. 1874 & G. Smith & SWP, NP/NT, IT \\
\hline i. 1878 -vii. 1882 & H./N. Rassam & IT, NP, NY, SWP \\
\hline i-ii. 1889 & E. A. W. Budge & SWP, NP, town \\
\hline ii. 1889 -xii. 1890 & N. Rassam & SWP, NP? \\
\hline x. 1901 & L. W. King & survey \\
\hline iii. 1903 -vi. 1904 & L. W. King & K, SWP, NP \\
\hline
\end{tabular}




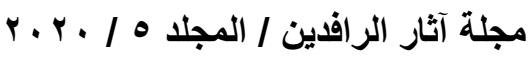

\begin{tabular}{|c|c|c|}
\hline Date & Excavator & Area \\
\hline vi. 1904 -ii. 1905 & R. C. Thompson & $\begin{array}{l}\text { SWP, NP, NT, } \\
\text { KEG }\end{array}$ \\
\hline x. 1927 -ii. 1928 & R. C. Thompson & NT, ONP, SH \\
\hline x. 1929 -ii. 1930 & R. C. Thompson & ONP, IT \\
\hline x. $1930-$ ii. 1931 & R. C. Thompson & IT \\
\hline x. $1931-$ ii. 1932 & R. C. Thompson & SWP, IT, SH \\
\hline 1941 & B. Y. Francis & Gate 10 \\
\hline iv. 1942 & M. Rowton & K \\
\hline v. 1942 & Royal Engineers & SWP/IT \\
\hline x. 1954 & $\begin{array}{l}\text { Mohammad Ali } \\
\text { Mustafa }\end{array}$ & $\begin{array}{l}\text { NY, Hermes } \\
\text { temple }\end{array}$ \\
\hline 1956 & M. al-'Ainachi & Gate 10 \\
\hline x. 1965 -iii. 1966 & T. Madhloom & SWP, Gates 4, 11 \\
\hline $1966-67$ & T. Madhloom & $\begin{array}{l}\text { SWP, wall, } \\
\text { Gates } 3,4,9,10\end{array}$ \\
\hline $1966-68$ & Amr Suleiman & Gate 9 \\
\hline $1967-68$ & T. Madhloom & $\begin{array}{l}\text { SWP, wall, } \\
\text { Gates } 4,12 \text {, town }\end{array}$ \\
\hline c. 1968 & B. Abu Soof & Gate 16 \\
\hline 1969 & T. Madhloom & $\begin{array}{l}\text { SWP, wall, } \\
\text { Gates 4, 12, } \\
\text { Hosr (tomb) }\end{array}$ \\
\hline $1970-71$ & T. Madhloom & $\begin{array}{l}\text { SWP, wall, } \\
\text { Gate } 12\end{array}$ \\
\hline $1971-72$ & Menhal Jabbar & $\begin{array}{l}\text { wall, Gates 4, } \\
12 \text {, "area } 59 \text { " }\end{array}$ \\
\hline 1973 & Menhal Jabbar & wall, Gates 9, 12 \\
\hline ii. 1974 & Menhal Jabbar & "bìt b̧ilāni" \\
\hline $1974-75$ & Menhal Jabbar & wall, Gate 12 \\
\hline c. 1975 & Mosul Awqaf & NY \\
\hline $1975-86$ & Menhal Jabbar & wall, Gate 12 \\
\hline 1980 & Menhal Jabbar & wall, Gate 2 \\
\hline $1980-81$ & Menhal Jabbar & wall, Gates 4,9 \\
\hline
\end{tabular}




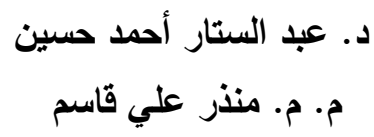

تاريخ التنقيبات الأثريَّة في مدينة نينوى

\begin{tabular}{l|l|l|}
\hline Date & Excavator & Area \\
\hline 1981 & Fadhil Abbas & Hosr (bridges) \\
\hline 1986 & Abd as-Sattar & NY \\
\hline 1987 & $\begin{array}{l}\text { M. L. Scott, } \\
\text { J. MacGinnis }\end{array}$ & Hosr (K terrace) \\
\hline $1987-1990$ & D. Stronach & \\
\hline v.-vi. 1987 & D. Stronach & KG, NWM \\
\hline iii-vi. 1989 & D. Stronach & $\begin{array}{l}\text { K, KEG, Hosr, } \\
\text { Gate 3, town }\end{array}$ \\
\hline iv-vi. 1990 & D. Stronach & $\begin{array}{l}\text { K, KEG, SWP, } \\
\text { Gate 3, town }\end{array}$ \\
\hline (*) 2011 -2013 & $\begin{array}{r}\text { Ali Y. } \\
\text { Aljubouri }\end{array}$ & NP \\
\hline
\end{tabular}

Abbreviations: IT = Ištar Temple; $\mathrm{K}=$ various parts of Kuyunjik; KEG = Kuyunjik East Gate; NP = North Palace; NWM = North-West Mound; NY = Nabi Yũnus; ONP = Old North Palace; SH = "Sennacherib's House"; SWP = South-West Palace. Dates of some seasons are approximate: further details on sponsors and staff are available in Haik $(1968,59-60 ; 1971,36-38)$ and Qahtan Salih $(1987,26-31)$.

(الشكل (ب)

ثبت بأسماء المئقبين في مدينة نينوى الأثرية والمناطق التي نقبوا فيها وتاريخ التنقيب منذ أول تنقيب في المدينة وحتى الآن

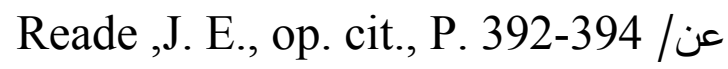
(*) تجدر الإثارة إلى أننا قمنا بإضافة الحقل الأخير من الجدول. 


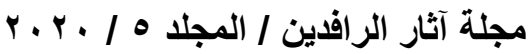
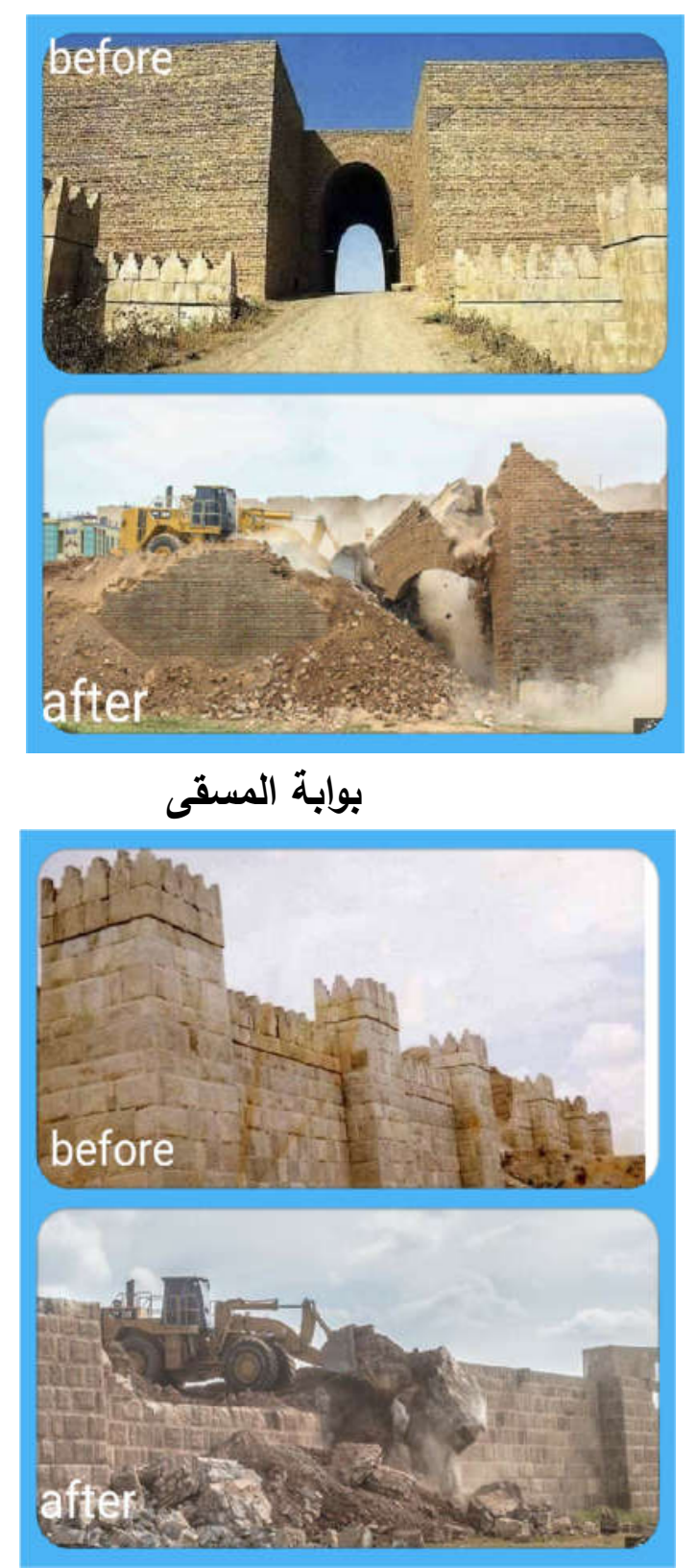

جانب من سور المدينة
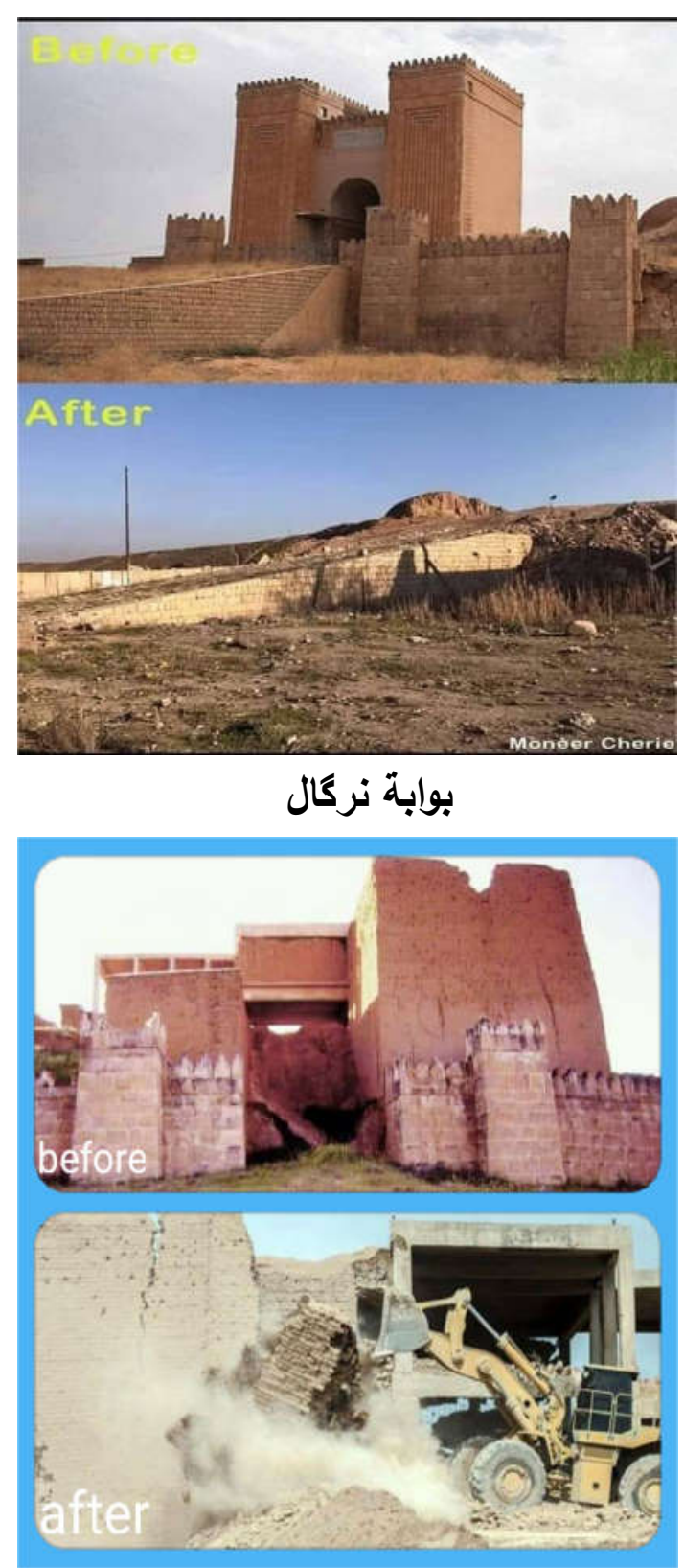

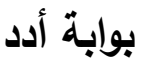

\section{الثكل ( ع ( )}

بوابات نينوى وسورها قبل التخريب ويعده 


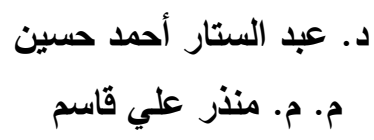

(1)Thompson, C., "The British museum excavation on the temple of Ishtar at Nineveh 1930-1931", Annals of Archaeology and Anthropology, 20 (1932), Liverpool, pp.100-110 .

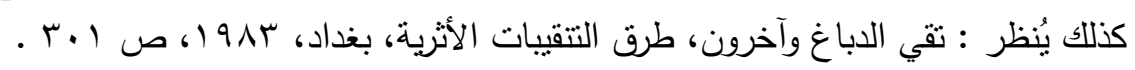

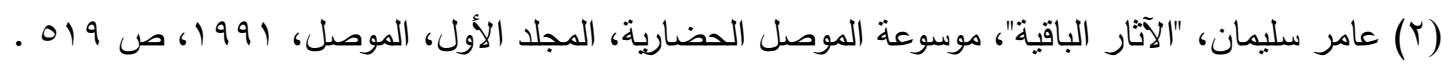

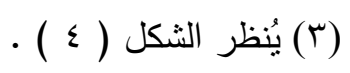

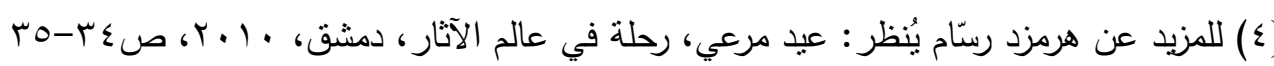

(5) Reade, J.E, "NINIVE(NINEVEH)", Reallexikon der Assyriology und Vorderasiatischen Archäologie, IX, 1998-2001, Berlin, P. 389.

(6) Ibid.

$$
\text { كذلك ينظر : }
$$

لابات، رينيه، قاموس العلامات المسمارية، ترجمة البير ابونا ووليد الجادر وخالا سالم اسماعيل، مراجعة

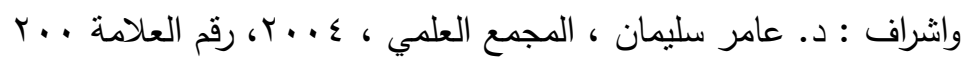

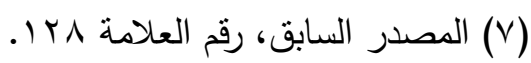

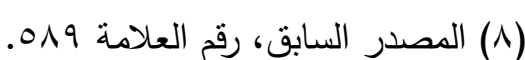

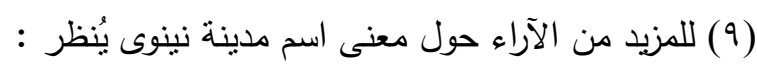

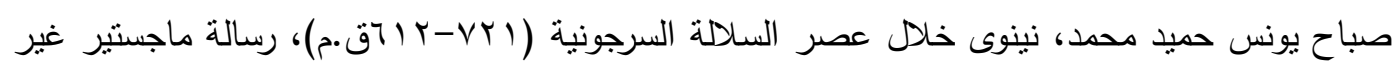

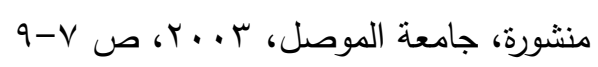

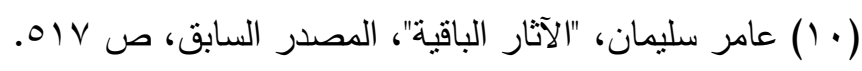

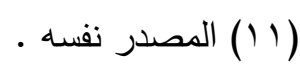

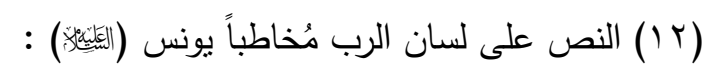

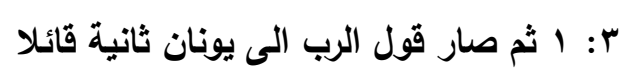

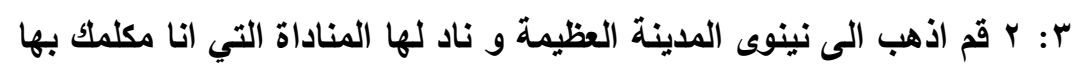

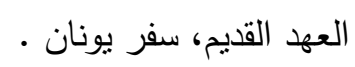

(ז (1) جابر خليل ابراهيم، "تخطيط المدن"، موسوعة الموصل الحضارية، المجلد الأول، الموصل، (99 19، ص

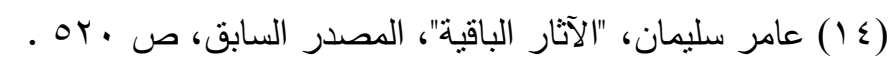

(10) محمد طه محمد الأعظمي، الأسوار والتحصينات الدفاعية في العمارة العراقية اطروحة دكتوراه غيرة البهاه

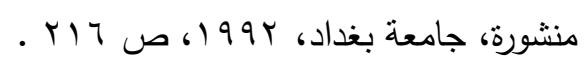

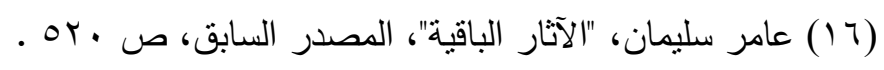

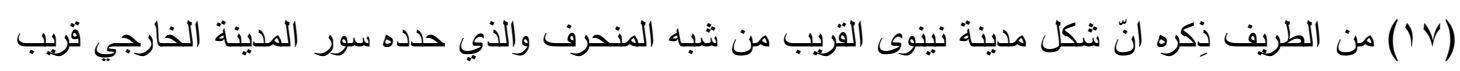

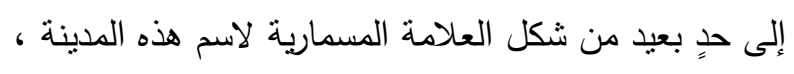

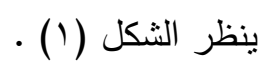




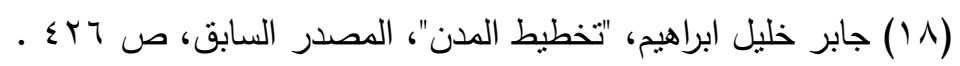
(9 (1) تجدر الإثارة إلى أنّ ما مكتشف من بوابات سور مدينة نينوى حتى الآن هو خمس عشرة بوابة، في حين

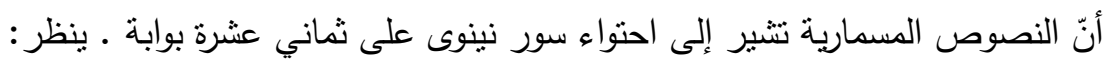
Reade, J.E. ,op. cit., pp. 401-403 .

(Y. عمار حسين مصطفى عبداله، بوابات العواصم والقصور الآشورية في ضوء الاكتثافات الأثرية الحديثة،

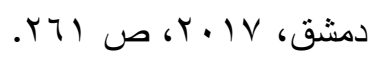

(Y) محمد حجاج الجميلي، نموذج تخطيط وبناء العواصم الآثورية الأربعة ، أطروحة دكتوراه غير منشورة،

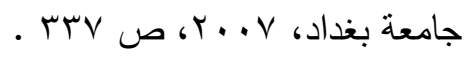

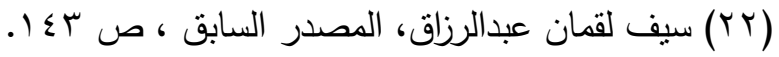

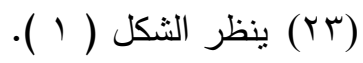

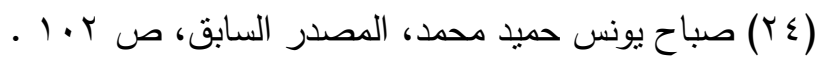

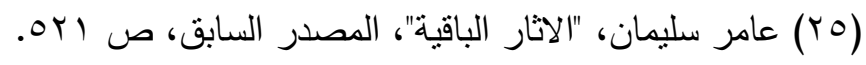

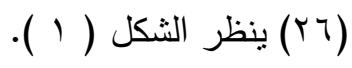

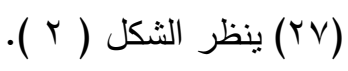

(28) Reade, J.E. ,op. cit., pp. 407-417 .

$$
\begin{aligned}
& \text { (Yq) عامر سليمان، "الاثار الباقية"، المصدر السابق، ص (1) (1) }
\end{aligned}
$$

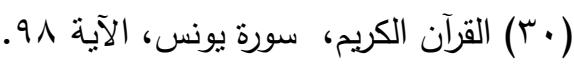

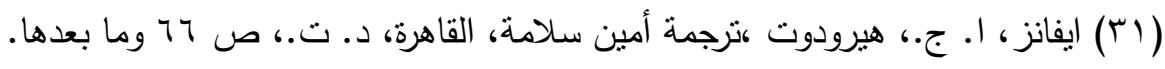

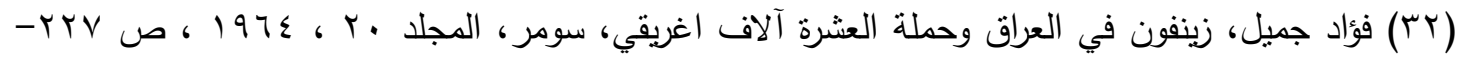

كذللك يُنظر: طه باقر، مقدمة في تاريخ الحضارات القديمة، جا، الوجيز في تاريخ حضارات وادي

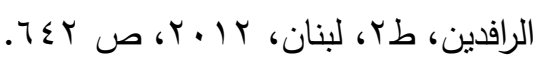

(Tr) عمر جسام فاضل العزاوي، علم الآتار في العراق نشأته ونظوره، رسالة ماجستير غير منشورة، جامعة

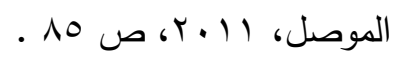

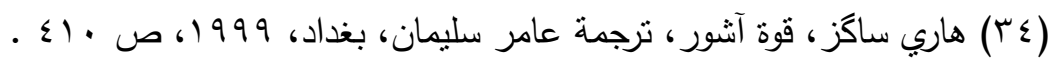

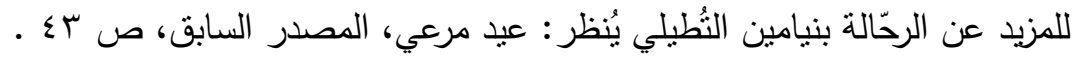

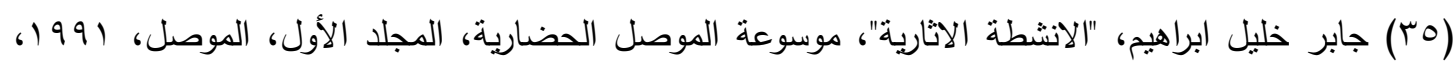

ص .q

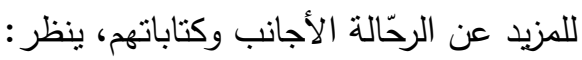

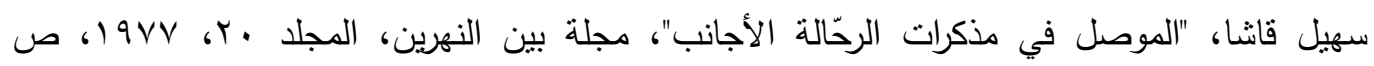

$$
\text { . . . - rAV }
$$

(Tr) ينظر الثكل (T) الخاص بقائمة بأسماء المُنقبين في مدينة نينوى الأثرية والمناطق التي نقبوا فيها وتاريخ

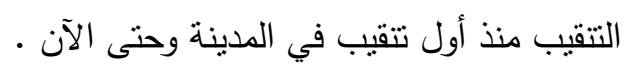

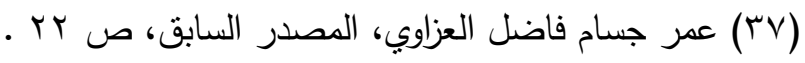




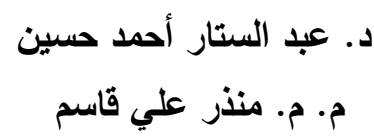

(ب^^) جابر خليل إبراهيم، "التتقيب في تل قوينجق: انجازات الماضي وآمال المستقبل"، مجلة آثار الرافدين، مجلد . T

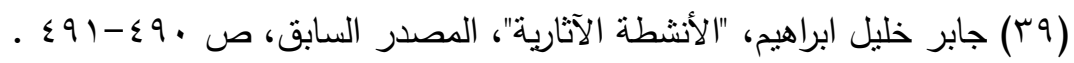

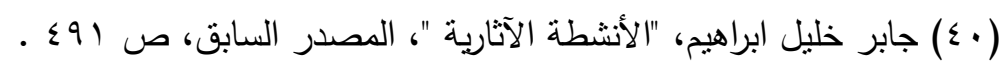

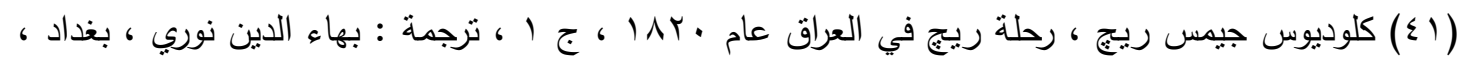
. 1901

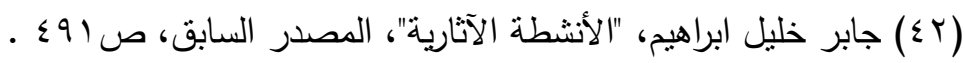
.(43) Fagan, B. M., Return to Babylon ,U.S.A., 2007, p. 98 .

Botta, P. E. , Monument de Ninive, tome I, II, III, Paris, 1849.

(45) George Smith, Assyrian discoveries an account of explorations and discoveries on the site of Nineveh during 1873 and 1873, New York, 1875, pp.2-3 .

$$
\begin{aligned}
& \text { كذلك بُنظر : تقي الدباغوآخرون، المصدر السابق، ص اس-بr . }
\end{aligned}
$$

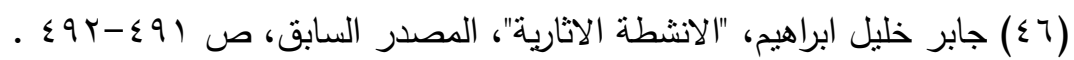

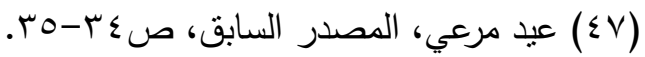

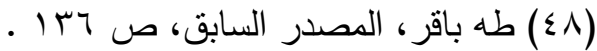

$$
\begin{aligned}
& \text { (9 §) جابر خليل ابراهيم، "الانشطة الاثارية"، المصدر السابق، ص موحـ ـ }
\end{aligned}
$$

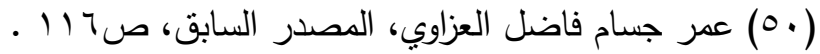

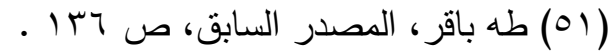

$$
\begin{aligned}
& \text { (Or) جابر خليل ابراهيم، "الانشطة الاثارية"، المصدر السابق، ص ؟9 ؛ ـ } \\
& \text { (ب) المصدر نفسه. }
\end{aligned}
$$

(54) .Reade, j. E., op. cit., p. 392 .

(00) جابر خليل ابراهيم، "الانشطة الاثارية"، المصدر السابق، ص ؟9 ؛ .

(7ه) للمزيد عن عالمِ المسماريات جورج سميث يُنظر : عيد مرعي، المصدر السابق، ص V م .

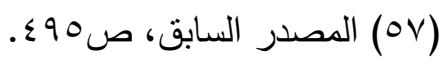

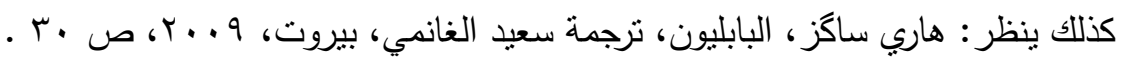

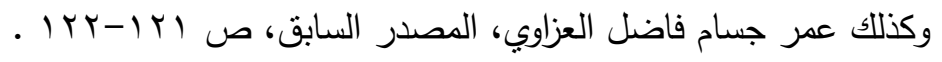

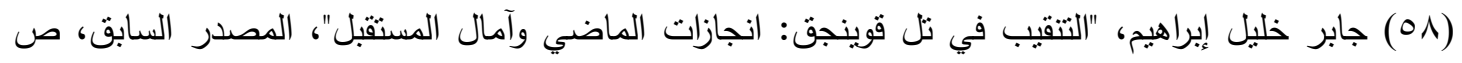

(ه9) للمزيد عن التنقيبات الألمانية في مدينتي بابل وآثنور الأثريتين ينظر:

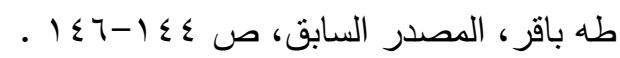

كذللك ينظر: بهنام ابو الصوف، "دور التتقيبات الاثرية في الكثف عن حضارة العراق القديم"، حضارة

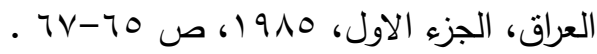


(60) Reade, J. E., op. cit., P. 392 .

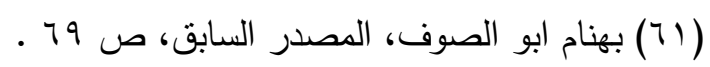

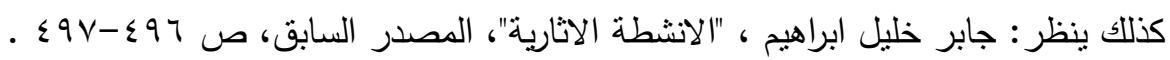

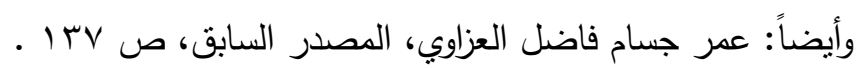

(62) Stronach, D., Notes On The Fall of Nineveh, Assyria 1995, Helsinki, 1997, p. 307

(63) Stronach, D., "Excavation at Nineveh, 1987", Sumer, 64 (1989-1990), pp. 107108 .

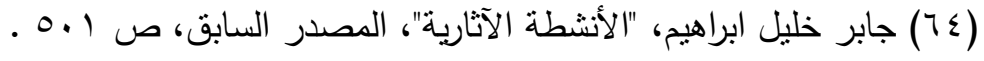

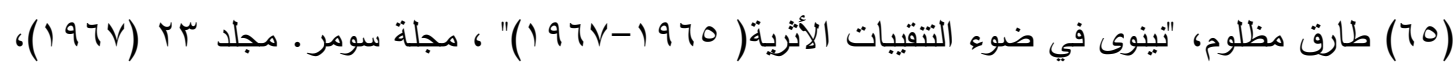

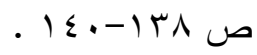

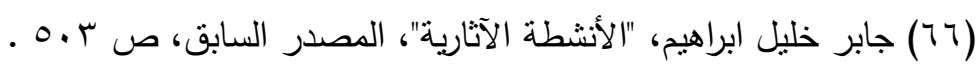

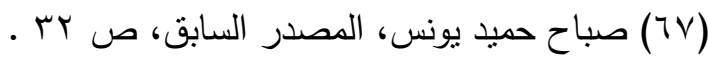

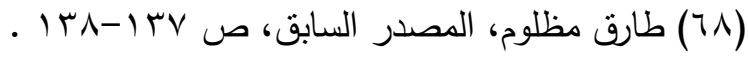

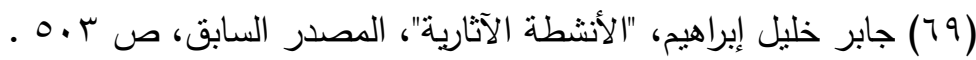

عامر سليمان، "نتائج حفريات جامعة الموصل في أسوار نينوى"، مجلة آداب الرافدين، العدد الأول، (V)

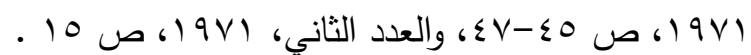

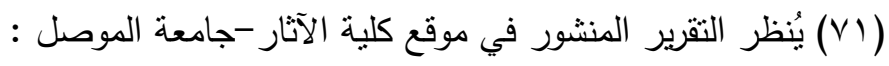

(archeology.uomosul.edu.iq) 



\section{Journal}

\section{AL- Rafedain Archaeology}

Accredited Scientific Journal

It Search's in Archaeology of Iraq and Ancient Near East

Published by College of Archaeology - University of Mosul

$$
\text { E_Mail:ali_aljuboori@yahoo.com }
$$



